Brooklyn Law School

BrooklynWorks

Faculty Scholarship

2010

Fannie Mae and Freddie Mac and the Future of Federal Housing

Finance Policy: A Study of Regulatory Privilege

David Reiss

Follow this and additional works at: https://brooklynworks.brooklaw.edu/faculty

Part of the Property Law and Real Estate Commons 


\title{
FANNIE MAE AND FREDdie MAC AND THE FUtURE OF FEDERAL HOUSING FinANCE POLICY: A STUdy of REGULATORY PRIVILEGE
}

\author{
David Reiss*
}

\begin{abstract}
The federal government recently placed Fannie Mae and Freddie Mac-the government-chartered, privately owned mortgage finance companies-in conservatorship. These two massive companies are profitdriven, but as government-sponsored enterprises, they also have a government-mandated mission to provide liquidity and stability to the United States mortgage market and to achieve certain affordable housing goals. How the two companies should exit their conservatorship has implications that reach throughout the global financial markets and are of key importance to the future of American housing finance policy.

While the American taxpayer will be required to fund a bailout of the two companies that will be measured in the hundreds of billions of dollars, the current state of affairs presents an opportunity to reform the two companies and the manner in which the residential mortgage market is structured. Few scholars, however, have provided a framework in which to conceptualize the possibilities for reform.

This Article employs regulatory theory to construct such a framework. A critical insight of this body of literature is that regulatory privilege should be presumed to be inconsistent with a competitive market, unless proven otherwise. The federal government's special treatment of Fannie and Freddie is an extraordinary regulatory privilege in terms of its absolute value, its impact on its competitors, and its cost to the federal government. Regulatory theory thereby clarifies how Fannie and Freddie have relied upon their hybrid public/private structure to obtain and protect eco-

* Associate Professor, Brooklyn Law School; B.A., Williams College; J.D., New York University School of Law. The author would like to thank the following people for helpful comments: Baher Azmy, Dana Brakman Reiser, James Fanto, Edward Janger, Roberta Karmel, Claire Kelly, Gerald Korngold, James Park, Thomas Stanton, Nelson Tebbe, Spencer Waller as well as workshop participants at the University of Colorado Law School, the University of Connecticut School of Law and Brooklyn Law School. The author also acknowledges the support of the Brooklyn Law School Summer Research Stipend Program. Thanks also to Sarah Castle, April Charleston, Philip Tucker, and Schuyler Weiner for excellent research assistance.
\end{abstract}


nomic rents at the expense of taxpayers as well as Fannie and Freddie's competitors.

Once analyzed in the context of regulatory theory, Fannie and Freddie's future seems clear. They should be privatized so that they can compete on an even playing field with other financial institutions and their public functions should be assumed by pure government actors. While this is a radical solution and one that would have been considered politically naïve until the recent credit crisis, it is now a serious option that should garner additional attention once its rationale is set forth.

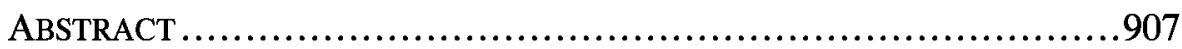

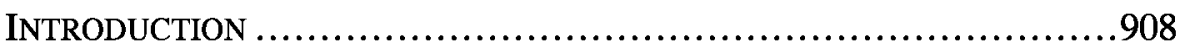

I. FANNIE AND FREDDIE AND THE CREDIT CRISIS ....................912

A. Fannie and Freddie's Business ..................................913

B. The Crisis Deepens .............................................916

C. Congress Responds: The Housing and Economic Recovery Act of 2008 ........................................................919

D. Improved Financial Safety and Soundness Regulation .............920

E. Temporary Government Support..................................922

F. Fannie and Freddie Enter Conservatorship .....................923

II. EVALUATING FANNIE AND FREDDIE ...............................924

A. Fannie and Freddie's Self-Assessment .........................925

1. Lower Overall Interest Rates for Homeowners ...............925

2. Systemic Stability and Liquidity ..........................927

3. Affordable Housing Goals ..................................928

4. Consumer Protection .........................................9930

B. Existing Theories of the Government-Sponsored Enterprise.......931

C. Fannie and Freddie Evaluated through the Lens of Regulatory

Theory ........................................................... 933

III. FANNIE AND FREDDIE's GSE STATUS SHOULD BE TERMINATED....944

A. Fannie and Freddie Are Political Powerhouses ....................944

B. The Government Guarantee Is a Reckless Budgeting Device......945

C. Fannie and Freddie Should Be Privatized.........................997

IV. CoNCLUSION ........................................................954

\section{INTRODUCTION}

As part of its response to the ongoing credit crisis, the federal government recently placed Fannie Mae and Freddie Mac, the governmentchartered, privately-owned mortgage finance companies, in conservator- 
ship. ${ }^{1}$ These two massive companies are profit-driven, but as governmentsponsored enterprises (GSEs) they also have a government-mandated mission to provide liquidity and stability to the United States mortgage market and to achieve certain affordable housing goals. ${ }^{2}$ How the two companies should exit their conservatorship is of key importance to the future of federal housing finance policy. Indeed, this question is of pressing importance as the Obama Administration has signaled that it would rely heavily on Fannie and Freddie as part of the short-term response to the foreclosure epidemic that has swept across America in the last couple of years. ${ }^{3}$ Once the acute crisis is dealt with, however, the Administration will need to put American housing finance policy on the right track for the long-term health of the system. This will require a framework for analyzing the needs of that system-a framework which this Article provides.

Fannie and Freddie are extraordinarily large companies: together, they own or guarantee more than forty percent of all the residential mortgages in the United States. ${ }^{4}$ This amounts to over 5.2 trillion dollars in mortgages. ${ }^{5}$ By statute, Fannie and Freddie's operations are limited to the "conforming" portion of the mortgage market, which is made up of mortgages that do not exceed an annually-adjusted threshold $\left(\$ 417,000\right.$ in 2009). ${ }^{6}$

1. See infra Part I.D.

2. See David Reiss, The Federal Government's Implied Guarantee of Fannie Mae and Freddie Mac's Obligations: Uncle Sam Will Pick up the Tab, 42 GA. L. REV. 1019, 1053-54 (2008). A GSE is "a federally chartered, privately owned, privately managed financial institution that has only specialized lending and guarantee powers and that bond-market investors perceive as implicitly backed by the federal government." Richard Scott Carnell, Handling the Failure of a Government-Sponsored Enterprise, 80 WASH. L. REV. 565, 570 (2005).

3. Sheryl Gay Stolberg \& Edmund L. Andrews, \$275 Billion Plan Seeks To Address Crisis in Housing, N.Y. TIMES, Feb. 19, 2009 at A1 (reporting that restrictions on Fannie and Freddie that keep them refinancing mortgages would be lifted); Jody Shenn \& Dawn Kopecki, Fannie, Freddie Focus on Obama's Mortgage Program, CEOs Say, BLOOMBERG.COM, Oct. 12, 2009, http://www.bloomberg.com/apps/news?pid = newsarchive\&sid =aFIx8bxb3FPg (reporting that a "main focus" of Fannie and Freddie's current business is supporting Obama Administration's mortgagemodification program).

4. See Federal Housing FinanCE AGEnCy (FHFA), ENTERPRise SHARE of Residential MORTGAGE DEBT OUTSTANDING: 1990-2009 [hereinafter "FHFA Chart"], http://www.fhfa.gov/web files $/ 15556 /$ Enterprise $\% 20$ share $\% 20$ of $\% 20$ Resident $\% 20$ Mortgage $\% 20$ Debt $\% 200$ utstanding $\% 201990$ \%202009.xls (showing outstanding mortgage debt through the end of 2009). Fannie Mae is formally known as the "Federal National Mortgage Association" and Freddie Mac is formally known as the "Federal Home Loan Mortgage Corporation," but they are universally referred to (even by themselves) by their nicknames. "Residential mortgages" include those for owner-occupied one to four family homes. See KimBerly BurnetT \& LindA B. Fosburg, Study of Multifamily UNDERWRITING AND THE GSES' ROLE IN THE MULTIFAMILY MARKET: EXPANDED VERSION $1 \mathrm{n} .18$ (report prepared for the U.S. Department of Housing and Urban Development by Abt Associates Inc., August 2001), available at http://www.abtassociates.com/reports/2001871779298_81131.pdf (last visited Sept. 30, 2010).

5. See FHFA Chart, supra note 4.

6. See Freddie MAC, Glossary of FinANCE AND ECONOMIC TERMS (A-F), http:// www.freddiemac.com/ smm/a_f.htm (last visited Sept. 22, 2010) (defining “conforming mortgage"); News Release, Conforming Loan Limit for U.S. To Remain $\$ 417,000$ in 2009; Different Limits in Some Areas, at 1 (Nov. 7, 2008), available at http:// www.fhfa.gov/ GetFile.aspx?FileID =135. See also infra notes 24-26 and accompanying text (describing conforming and jumbo mortgage markets). 
The two companies effectively have no competition in the conforming sector of the mortgage market because of advantages granted to them by the federal government in their charters. ${ }^{7}$ The most significant of these advantages has been the federal government's implied guarantee of Fannie and Freddie's debt obligations. ${ }^{8}$ The implied guarantee allowed Fannie and Freddie to borrow funds more cheaply than their fully private competitors and thereby offer the most attractive pricing in the conforming market. ${ }^{9}$ As the two companies have grown immense, numerous commentators and government officials have called for their reform; Fannie and Freddie's powerful lobbying forces, however, had kept these reformers mostly at bay. ${ }^{10}$

As a result, Fannie and Freddie continued to grow at a rapid rate through the early 2000 s, until they were each hit by accounting scandals. ${ }^{11}$ In response to those scandals, Congress and the two companies' regulators began to take various steps to limit their growth. ${ }^{12}$ But once they stabilized in 2007, the current credit crisis commenced and their market share began to increase once again as other lenders could not raise capital to lend to borrowers. ${ }^{13}$ At first, many commentators believed that Fannie and Freddie would ride the crisis relatively unscathed, but it turned out that they had much more exposure to the problems in the toxic subprime and Alt-A portions of the mortgage market than they had let on in their public disclosures. ${ }^{14}$

Because of their poor underwriting, the two companies started posting quarterly losses in 2007 that ran into the billions of dollars, with larger losses on the horizon. ${ }^{15}$ As a result, they had trouble complying with the capital requirements set by their regulator. ${ }^{16}$ Their problems began to spiral out of control along with those of the rest of the financial sector until

As discussed in the text accompanying note 81 infra, this loan limit has been increased in certain ways during the credit crisis.

7. See Reiss, supra note 2 , at 1033.

8. See generally id. The Housing and Economic Recovery Act of 2008 (the "Act") appears to have made the implicit guarantee a bit more explicit as it gives the Treasury broad power to assist Fannie and Freddie if one or both were to become insolvent. Pub. L. No. 110-289 (2008), 122 Stat. 2654; see infra Part I (discussing impact of Act on implicit guarantee).

9. See generally Reiss, supra note 2 , at 1033.

10. See infra note 149 and accompanying text.

11. See Reiss, supra note 2, at 1036-40; Thomas H. Stanton, The Life Cycle of the GovernmentSponsored Enterprise: Lessons for Design and Accountability, 67 PUB. ADMIN. REV. 837, 840-842 (2007), available at http://onlinelibrary.wiley.com/doi/10.1111/j.1540-6210.2007.00772.x/pdf (last visited Sept. 22, 2010).

12. See Stanton, supra note 11 , at $840-44$.

13. Damian Paletta \& James R. Hagerty, U.S. Puts Faith in Fannie, Freddie-Firms, Once Hemmed in, Are Freed for Bigger Role in Aiding Mortgage Market, WALL ST. J., Mar. 20, 2008, at A3 (estimating that Fannie and Freddie would "buy or guarantee $80 \%$ of all new home loans" in 2008).

14. See infra Part I.B.

15. See id.

16. See id. 
then-Secretary of the Treasury Henry M. Paulson Jr. asked that Congress give the Treasury the authority to take over the two companies if they were not able to meet their financial obligations. Congress, with remarkable alacrity, passed the Housing and Economic Recovery Act of 2008 in the summer of 2008. Soon thereafter Paulson decided that the two companies were flirting with insolvency and placed them in conservatorship, pursuant to the Act. $^{17}$

While the American taxpayer will likely be required to fund a bailout of the two companies that will be measured in the hundreds of billions of dollars, the current state of affairs presents an opportunity to reform the two companies and the manner in which the mortgage market is structured. Though the need for reform is evident, few scholars have considered the issue systematically. Scholars have, however, built up a significant base of knowledge about what works well and what does not work well with public/private hybrids like Fannie and Freddie.

Contemporary theories of regulation persuasively argue that special interests work to bend the tools of government to benefit themselves. This Article, relying on regulatory theory, provides a framework with which to conceptualize the possibilities for reform by viewing Fannie and Freddie as creatures of regulatory privilege. A critical insight of regulatory theory is that regulatory privilege should be presumed to be inconsistent with a competitive market, unless proven otherwise. The federal government's special treatment of Fannie and Freddie is an extraordinary regulatory privilege in terms of its absolute value, its impact on its competitors, and its cost to the federal government. As such, regulatory theory offers a fruitful resource for academics and policymakers considering reform of Fannie and Freddie's privileged status because it clarifies how Fannie and Freddie have relied upon their hybrid public/private structure to obtain and protect economic rents at the expense of homeowners as well as Fannie and Freddie's competitors.

Once analyzed in the context of regulatory theory, Fannie and Freddie's future seems clear. They should be privatized so that they can compete on an even playing field with other financial institutions and their public functions should be assumed by government actors. While this is a radical solution and one that would have been considered politically naïve until the recent credit crisis, it is now a serious option that should garner additional attention once its rationale is set forth.

In an earlier article, I provided a comprehensive analysis of the regulatory privilege that Fannie and Freddie enjoy. ${ }^{18}$ This Article builds on that work to situate that privilege within a broader understanding of regulatory

17. See infra Part I (reviewing events leading up to Fannie and Freddie entering conservatorship).

18. See Reiss, supra note 2 . 
theory and to explain the rare hybrid public/private nature of the privilege that Fannie and Freddie enjoy. In doing so, this Article argues that the existing regulation of the two companies should be brought in line with our current understanding of how government should be deploying its power in the private sector.

This Article proceeds as follows: Part I will describe Fannie and Freddie's role in the secondary market for residential mortgages. After describing what happened to the two companies in the credit crisis that commenced in 2007, it will outline the key provisions of the Housing and Economic Recovery Act of 2008, which authorized the federal government to place Fannie and Freddie in conservatorship.

Part II then shifts to construct a theoretical framework with which to evaluate Fannie and Freddie. Part II.A presents Fannie and Freddie's assessment of their own roles in the secondary residential mortgage market. Part II.B reviews how other scholars have conceptualized the role of Fannie and Freddie in the housing finance market. Part II.C then evaluates the operation of Fannie and Freddie in the context of six policy goals that derive from contemporary regulatory theory: (i) maintaining competition, (ii) efficiently allocating society's goods and services, (iii) promoting innovation, (iv) preventing inappropriate wealth transfers, (v) preserving consumer choice, and (vi) preventing an overly-concentrated economy. It finds that Fannie and Freddie come up short under nearly all of those goals.

Based on the conclusion of Part II that Fannie and Freddie no longer have a net positive impact, Part III argues that the two companies should be privatized. It also argues that the benefits that Fannie and Freddie produce in the residential mortgage market should be maintained through alternative means, including financial regulation, consumer protection legislation, and increased subsidies for affordable housing.

\section{FANNIE AND FREDDIE AND THE CREDIT CRISIS}

This Part begins by explaining what Fannie and Freddie do in the mortgage markets. It then describes how they fared in the credit crisis that commenced in 2007 . This brief history opens with the early phase of the credit crisis in which the two companies were perceived as potential white knights, mounting a defense of the distressed secondary mortgage market. It then details their own troubles that led to the enactment of the Housing and Recovery Act of 2008. It concludes with the government placing them in conservatorship as the financial condition of the two companies rapidly disintegrated. 


\section{A. Fannie and Freddie's Business}

Fannie and Freddie have two primary lines of business. ${ }^{19}$ First, they provide credit guarantees so that groups of residential mortgages can be packaged as residential mortgage-backed securities (RMBS). Second, Fannie and Freddie purchase residential mortgages and related securities with borrowed funds. Because of the federal government's implied guarantee of their debt securities, Fannie and Freddie have been able to profit greatly from this second line of business. This is because they can make money on the spread between their low cost of funds and what they must pay for the mortgage-related investments in their portfolios. ${ }^{20}$

Fannie and Freddie's charters restrict the mortgages they may buy. ${ }^{21}$ In general, they may only buy mortgages with loan-to-value ratios of $80 \%$ or less unless the mortgage carries mortgage insurance or other credit support ${ }^{22}$ and may not buy mortgages with principal amounts greater than an amount set each year (the 2009 conforming-loan limit for a single-family home is $\$ 417,000$ ). ${ }^{23}$ Loans that Fannie and Freddie can buy are known as "conforming" loans. ${ }^{24}$ Loans that exceed the loan amount limit in a given year are known as "jumbo" loans. ${ }^{25}$ Most of the remainder of the RMBS market belongs to "private label" firms which securitize (i) jumbo mortgages and (ii) subprime mortgages that Fannie and Freddie cannot or choose not to guarantee or purchase for their own portfolio. ${ }^{26}$

19. See Fannie Mae's Business FAQ, http://www.fanniemae.com/faq/faq2.jhtml?p=FAQ (last visited Sept. 22, 2010) (describing Fannie Mae's business); Freddie Mac: Our Business, http://www.freddiemac.com/corporate/company_profile/our_business (last visited Sept. 22, 2010) (describing Freddie Mac's business). For a more in-depth description of Fannie and Freddie's business model, upon which this brief description is based, see Reiss, supra note 2, at 1027-33.

20. See Fannie Mae's Business FAQ, supra note 19 (describing Fannie Mae's business); Freddie Mac: Our Business, supra note 19 (describing Freddie Mac's business). See also ERIC WEISS,

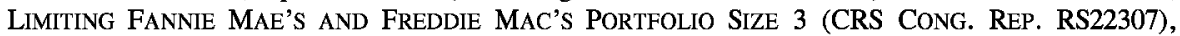
available at http://www.policyarchive.org/handle/10207/bitstreams/4255.pdf (last visited Sept. 22, 2010) (noting that their portfolio activities give Fannie and Freddie what amounts to a funding advantage over the private market "that appears to be unlimited").

21. Wayne Passmore et al., GSEs, Mortgage Rates, and the Long-Run Effects of Mortgage Securitization, 25 J. REAL EST. FIN. \& ECON. 215, 217 (2002).

22. See 12 U.S.C. $\S 1454(\mathrm{a})(2)$ (2006) (providing restrictions for Freddie Mac); id. $\S 1717(\mathrm{~b})(2)$ (providing restrictions for Fannie Mae).

23. See News Release, Conforming Loan Limit for U.S. To Remain $\$ 417,000$ in 2009 , supra note 6.

24. See Freddie MaC, Glossary of FinANCE AND Economic Terms (A-F), supra note 6 (defining "conforming mortgage").

25. See Eric Bruskin et al., The Nonagency Mortgage Market: Background and Overview, in THE HANDBOOK OF NONAGENCY MORTGAGE-BACKED SECURITIES 6-7 (Frank J. Fabozzi et al. eds., 2d ed. 2000). Jumbo loans (and other loans not purchased by Fannie and Freddie) have higher interest rates than those that are purchased by Fannie and Freddie in part because the originators of jumbo loans have a higher cost of funds. See Reiss, supra note 2, at 1033.

26. See Robert Van Order, The U.S. Mortgage Market: A Model of Dueling Charters, $11 \mathrm{~J}$. HOUSING RES. 233, 237 (2000). Since the credit crisis began, much of the private label RMBS securitization market has become “dormant." Nick Timiraos \& Ruth Simon, Smaller Mortgage Lenders See Opportunity in Turmoil, WALL ST. J., Dec. 2, 2008, at C1. 
Because Fannie and Freddie have so dominated the conforming sector of the mortgage market, they have standardized that sector by promulgating buying guidelines that lenders must follow if they want to sell their mortgages to either of the two companies. ${ }^{27}$ As I have noted in a previous article, "[s]uch standardization has led to increases in the liquidity and attractiveness of mortgages as investments to a broad array of investors." ${ }^{28}$

The government guarantee of Fannie and Freddie's debt obligations is a regulatory privilege that arose from Congress's efforts to create a national secondary residential mortgage market. It is the characteristic that allows them to borrow more cheaply than other financial institutions. It is the characteristic that allows them to completely dominate the prime conforming mortgage market. And it is the characteristic that poses the greatest threat to the federal government and the American taxpayer. One must therefore properly account for it in order to understand Fannie and Freddie.

Unlike true monopolists, Fannie and Freddie's market power is limited by the nature of their competitive advantage: in an otherwise efficient market, the maximum amount that they can retain as economic rent is the spread between the interest rates they must pay and those that their competitors must pay. ${ }^{29}$ Nonetheless, Fannie and Freddie share a key characteristic in common with government-granted monopolies: a legallycreated and overwhelming competitive advantage in a particular market, which translates into higher prices for consumers than would exist if Fannie and Freddie did not retain a portion of their economic rent for themselves. ${ }^{30}$

Because of their government guarantee, Fannie and Freddie were thought to be well-situated when the current credit crisis commenced. As other lenders began to fail and the secondary market for subprime mortgages dried up in 2007, a Citigroup report suggested that Fannie and Freddie could easily ride out the turmoil in the mortgage markets. ${ }^{31}$ Even more, some commentators were arguing that Fannie and Freddie would be

27. See Thomas H. Stanton, A State of Risk: Will Government-SPonsored EnTERPrises Be The NeXT FinANCIAL CRISIS? 86 (1991).

28. See Reiss, supra note 2, at 1032.

29. Economic rent is a return in excess of opportunity cost. See Michael A. Crew \& Charles K. Rowley, Feasibility of Deregulation: A Public Choice Analysis, in DEREGUlation AND DiverSifiCATION OF UTILITIES 5, 12 (Michael A. Crew ed., 1989); see also Jonathan R. Macey, Transaction Costs and The Normative Elements of The Public Choice Model: An Application to Constitutional Theory, 74 VA. L. REV. 471, 472 n.4 (1988) ("Rent-seeking refers to the attempt to obtain economic rents (i.e., rates of return on the use of an economic asset in excess of the market rate) through governmental intervention in the market.").

30. See infra Part II.B.

31. See James R. Hagerty, Fannie, Freddie Are Said To Suffer in Subprime Mess, WALL ST. J., July 28, 2007, at A3 (reporting that Citigroup indicated that while subprime mortgage bonds held by Fannie and Freddie have fallen in value, the two companies could "easily ride out" the subprime market turmoil). 
able to bail out other mortgage market players by buying additional mortgages. ${ }^{32}$ At the same time, however, some were raising the alarm that Fannie and Freddie could face some of the same problems that other mortgage lenders had been facing. ${ }^{33}$ But this view was overtaken in 2007 by the more dominant one which saw Fannie and Freddie as saviors of the mortgage markets.

This was a happy development for Fannie and Freddie because it meant that the terms of the debate regarding their appropriate role in the mortgage markets went from one in which the Executive Branch was beating the drums to limit their growth to one in which politicians and mortgage executives were calling for their role to be significantly expanded. ${ }^{34}$ Fannie and Freddie quickly tried to capitalize on this change in their political fortunes, advocating for an increased role in the crisis. ${ }^{35}$ At the earliest stage of the credit crisis, the Bush Administration continued to oppose an expansion of Fannie and Freddie's roles. ${ }^{36}$ As the crisis progressed, the regulator of the two companies began to signal that they were considering some expansions in Fannie and Freddie's role. ${ }^{37}$ The Federal Reserve,

32. See, e.g., John Authers, The Short View, Fin. TiMES, Aug. 7, 2007, at 15; see James R. Hagerty, Mortgage Crisis Extends its Reach-Fannie, Freddie Regain Dominance as Investors Shrink from Housing, WALL ST. J., Nov. 13, 2007, at A1 (reporting that Fannie and Freddie were continuing to fund mortgages and take on additional risk); Stacey-Marie Ishmael, CIT To Sell Subprime Book to Freddie Mac, FIN. TIMES, Sept. 20, 2007, at 17 (reporting that CIT Group will sell its subprime loan portfolio to Freddie Mac and quit the residential mortgage business).

33. See, e.g., Robert Cyran \& Martin Hutchinson, False Hopes for Mortgage Lengers, WALL ST. J., Aug. 9, 2007, at C10 (warning that Frannie and Freddie were over leveraged).

34. See, e.g., James R. Hagerty, Big Fans for Fannie, Freddie, WALl ST. J., Aug. 8, 2007, at C1 (noting that Senators Christopher Dodd and Charles Schumer have called for lifting cap on Fannie and Freddie's portfolios of mortgages and related securities); Angelo R. Mozilo, Commentary, Calling Fannie and Freddie, WALL ST. J., Dec. 5, 2007, at A24 (CEO of Countrywide Financial Corp. promoting increased role for Fannie and Freddie to temporarily provide support for the housing market); Damian Paletta, Democrats Propose Mortgage Aid, WALL ST. J., Oct. 4, 2007, at A5 (reporting that House Financial Services Committee Chair Barney Frank will support temporary increase in portfolios of Freddie Mac and Fannie Mae by $10 \%$ for one year in effort to ease credit crunch); Damian Paletta, Schumer Wants to Soften Limits on Fannie, Freddie, WALL ST. J., Sept. 10, 2007, at A3 (reporting that Senator Schumer plans bill to temporarily loosen constraints on government-sponsored Fannie and Freddie and increase size of mortgages they can purchase in high-cost areas).

35. See, e.g., Jeremy Grant, Fannie Mae Offer To Ease Subprime Pain Rebuffed by Regulator, FIN. TIMES, Aug. 11, 2007, at 3 (reporting that Fannie CEO unsuccessfully requested that OFHEO increase the cap on its portfolio); see Stacy-Marie Ishmael et al., Freddie Mac Chief Warns of Recession, FIN. TIMES, Sept. 28, 2007, at 27 (reporting Freddie CEO chief remarks regarding how Fannie and Freddie could be used to alleviate the credit crisis); Damian Paletta, OFHEO Is Pressured over Mortgages, WALL ST. J., Oct. 24, 2007, at B10 (reporting that OFHEO had received numerous letters from lawmakers and others urging it to allow Fannie and Freddie to increase the size of their portfolios).

36. See, e.g., Grant, supra note 35, at 3; Deborah Solomon, How FHA Could Help Homeowners, Wall ST. J., Aug. 22, 2007, at A6 (noting that President Bush balked at allowing Fannie and Freddie to buy more mortgages to ease credit crunch); Deborah Solomon, Paulson Confident on Economy, WALL ST. J., Sept. 12, 2007, at A3 (reporting Treasury Secretary Paulson's opposition to allowing Fannie and Freddie to grow in effort to relieve credit crisis).

37. See, e.g., Damian Paletta, Limits of Fannie, Freddie Could Be Lifted, WALl ST. J., Sept. 22, 2007, at A4 (reporting that OFHEO says limits on Fannie and Freddie's portfolios could be lifted by 
which had also been calling for limitations on Fannie and Freddie before the credit crisis struck, also began to publicly consider a greater role for the two firms. ${ }^{38}$

\section{B. The Crisis Deepens}

As Fannie and Freddie's political star began to appear ascendant, troubling accounts of possible losses started to appear; their underwriting models had been too optimistic and had not accounted for the possibility of severe reductions in housing prices across the nation. ${ }^{39}$ These fears were confirmed soon thereafter, as Fannie and Freddie began to report very large losses. ${ }^{40}$ These losses meant that Fannie and Freddie did not have the capital to expand their role in the mortgage markets and that their political star began its fall once again. ${ }^{41}$ The large losses led both companies to seek infusions of fresh capital. ${ }^{42}$ By this point, the federal government was now concerned both with Fannie and Freddie's viability as well as with the health of the overall market. ${ }^{43}$ Nonetheless, the federal government was running out of policy responses to the credit crisis, and Fannie and Freddie were seen as some of the few remaining possible agents that could execute federal policy.

By the beginning of 2008, the Bush Administration and Congress were seriously considering various initiatives to create more funding for mort-

February 2008 if both begin filing timely and audited financial statements).

38. See Damian Paletta, Idea of Jumbo-Loan Guarantee Is Floated, WALL ST. J., Nov. 9, 2007, at A2 (reporting that Federal Reserve Chair Ben Bernanke had suggested letting Fannie and Freddie securitize mortgages that are too large for them to buy, but letting government guarantee them).

39. See, e.g., James R. Hagerty, Fannie, Freddie Feel Default Heat, WALL ST. J., Nov. 19, 2007 , at A14 (reporting that a wave of defaults resulting from fall in home values and sales has hit Fannie and Freddie's usually more stable borrowers, and that the two companies also have significant exposure to subprime loans).

40. See, e.g., James R. Hagerty, Mortgage Giant Fuels Worries with Steep Loss, WALL ST. J., Nov. 21, 2007, at A1 (reporting that Freddie Mac had wider-than-expected third-quarter loss of $\$ 2.03$ billion which follows Fannie Mae's \$1.4 billion loss); see also Reiss, supra note 2, at 1031-32 (discussing risks inherent in the Fannie/Freddie business model).

41. See, e.g., Stephen Joyce, Government-Sponsored Enterprises Downbeat Earnings Reports Could Affect GSE's Role in Resolving Subprime Troubles, 89 BANKING REP. 864 (Nov. 26, 2007); Jeremy Grant and Krishna Guha, Tough Stance on Freddie, Fannie Is Vindicated, FIN. TIMES, Nov. 26,2007 , at 6 .

42. See James R. Hagerty, Fannie Mae Hurries To Raise \$7 Billion, WALL ST. J., Dec. 5, 2007, at A3 (reporting that Fannie and Freddie planned to raise billions through stock sales); see James R. Hagerty, Freddie Seeks To Put Losses Into Context, WALL ST. J., Dec. 12, 2007, at B4 (reporting that Freddie Mac was trying to persuade investors that its recent results are not quite as bad as accounting practices make them appear).

43. See R. Christian Bruce, Fannie Mae, Freddie Mac Could Get Relief on Surplus Capital Mandate, Lockhart Says, 89 BANKING REP. 1028 (Dec. 17, 2007) (reporting that OFHEO might consider easing or lifting a targeted $30 \%$ capital surplus mandate on Fannie/Freddie in 2008); Damian Paletta, Grip on Freddie, Fannie May Ease, WALL ST. J., Jan. 17, 2008, at A3 (reporting that Treasury Department had privately given Fannie and Freddie proposal to establish looser standards for how government approves debt issued by both firms). 
gages, a number of which were implemented. ${ }^{44}$ As part of the Economic Stimulus Act of 2008, enacted in February 2008, Fannie and Freddie were temporarily allowed to buy or guarantee mortgages with principal amounts as high as $\$ 729,750$ in order to restore liquidity to at least a portion of the jumbo sector. ${ }^{45}$ Fannie and Freddie's safety and soundness regulator, the Office of Federal Housing Enterprise Oversight (OFHEO), also lifted Fannie and Freddie's portfolio accounts caps and repeatedly lowered capital requirements in order to help respond to the housing slump and expand the supply of credit for mortgages. ${ }^{46}$

These steps seemed to have had the intended effect of increasing the supply of credit available for mortgages. ${ }^{47}$ Some commentators, however, were still warning that Fannie and Freddie continued to be heavily exposed to losses resulting from the housing slump that they were supposed to be alleviating. ${ }^{48}$ The market also began to worry about Fannie and

44. See James R. Hagerty, The Stimulus Package: More Risk for Fannie, Freddie?, WALL ST. J., Jan. 25, 2008, at A8 (reporting that Bush Administration was considering raising conforming limits); Damian Paletta, Plans would Boost Funds for Mortgages, WALL ST. J., Mar. 18, 2008, at A6 (reporting that Bush Administration was planning initiatives to create more funding for mortgages by relaxing constraints on Fannie and Freddie); Damian Paletta \& James R. Hagerty, U.S. Puts Faith in Fannie, Freddie, WALL ST. J., Mar. 20, 2008, at A3 (reporting that new loosened capital requirements will allow Fannie and Freddie to purchase additional $\$ 200$ billion of mortgage securities, equivalent to about $10 \%$ of expected US home-mortgage lending this year).

45. See Economic Stimulus Act of 2008, Pub. L. No. 110-185 § 201, 122 Stat. 613, 619-20 (2008) (enacted Feb. 13, 2008); Press Release, Office of Fed. Housing Enterprise Oversight, Temporary Conforming Loan Limits Released for High-Cost Areas, at 1 (Mar. 6, 2008), available at http://www.fhfa.gov/webfiles/2263/3608TempCLLreleased.pdf (last visited Sept. 24, 2010).

46. See Francesco Guerrera et al., Fannie-Freddie Caps Lifted amid Deepening Gloom, FIN. TIMES, Feb. 28, 2008, at 1; Michael Mackenzie \& Joanna Chung, Regulator Boost for Fannie Mae, FIN. TIMES, May 7, 2008, at 15 (reporting that OFHEO lowered Fannie's capital requirement in March and May). The portfolio caps were imposed by the federal government in response to concerns that Fannie and Freddie had grown too large and were not adequately protecting against risk. See Damian Paletta, Freddie Mac Will Voluntarily Cap Yearly Mortgage-Portfolio Growth, WALL ST. J., Aug. 2, 2006, at A2.

47. See Michael R. Crittenden, Some Progress Cited at Fannie and Freddie, WALL St. J., Apr. 16, 2008, at A2 (reporting that OFHEO found that Fannie and Freddie helped provide stability and liquidity to U.S. mortgage market in 2007 , but also warning of matters requiring attention, including Freddie's internal controls and corporate governance and Fannie's relatively aggressive strategy for managing risk); James R. Hagerty, Fannie, Freddie Report Progress in Cutting Some Mortgage Rates, WaLl ST. J., May 23, 2008, at A5 (reporting that Fannie and Freddie executives tell House Financial Services Committee they are bringing down interest rates on some jumbo mortgages); Saskia Scholtes, Data Show Fannie and Freddie Taking The Wheel in Home Loans, FIN. TIMES, Apr. 3, 2008, at 19 (reporting that Fannie and Freddie accounted for a record $75 \%$ of new mortgage financing at the end of 2007 , twice the share they held at end of 2006).

48. See Antony Currie \& Lauren Silva, Buck Up, Fannie \& Freddie, WALL ST. J., Mar. 14, 2008 , at C12 (column warning that if housing prices were to fall another $15 \%$ in 2008 , Fannie and Freddie could find themselves running short of capital); Peter Eavis, Fannie, Freddie May Have Further to Fall, WALL ST. J., Feb. 29, 2008, at C2 (column warning investors that Freddie increased its leverage in fourth quarter and is more exposed than before to downturns in its business of guaranteeing mortgages, and noting that Fannie's leverage remains at level far above that of other financial institutions); James R. Hagerty, Pressure on Fannie and Freddie, WALl ST. J., Mar. 11, 2008, at A3 (reporting that shares of Fannie and Freddie fall on fears that home-mortgage defaults will force companies to raise more capital); David Reilly \& Peter Eavis, Will \$6 Billion Do for Fannie?, WALL ST. J., May 7, 2008, at C26 (reporting that Fannies will raise $\$ 6$ billion through stock sale, but warning 
Freddie's solvency, as the yields on their debt widened by 30 basis points (a basis point is equal to $1 / 100$ of a percentage point) to trade at a historically high 40 basis points above LIBOR in mid-March. ${ }^{49}$ By May, more and more parties were concerned about the solvency of the two companies, and Congress and the Bush Administration were seriously negotiating an overhaul of Fannie and Freddie's "safety and soundness" OFHEO, to increase its ability to oversee and regulate the two companies. ${ }^{51}$

By mid-July, the market's serious concerns about Fannie and Freddie's viability were reflected in their stock prices, which were at their lowest level in more than sixteen years. ${ }^{52}$ The federal government, on the heels of the Bear Stearns bailout, took decisive action to prevent another acute crisis in the financial markets. The Treasury Department announced that it was seeking broad authority from Congress to support Fannie and

that this may not be sufficient to shore up its balance sheet while also assisting the liquidity of the housing market); Saskia Scholtes, Freddie Mac Decides against Raising Capital, FIN. TIMES, Mar. 13,2008 , at 42 (reporting that Freddie Mac ruled out any plans to raise new equity capital and rejected mounting speculation that it may not have enough capital to weather the housing slump).

49. See Saskia Scholtes, Shock Widening in Spreads of Fannie and Freddie Debt, FIN. TIMES, Mar. 18, 2008, at 25 (noting that, historically, Fannie and Freddie debt has traded from 10 to 20 basis points below LIBOR); see also Mark Gongloff, Are Fannie and Freddie Good as Gold?, WALL ST. J., May 6, 2008, at C1 (column contending that rise in mortgage delinquencies seems unlikely to reverse as long as home prices keep falling, which means more losses and need for more capital for Fannie and Freddie; cautions that shareholders may not be rescued even if government safety net catches Fannie and Freddie); James R. Hagerty \& Serena Ng, Mortgage Giants Take Beating on Fears over Loan Defaults, WALL ST. J., July 8, 2008, at A1 (reporting that Fannie and Freddie shares down due to fear that companies will have to issue billions of dollars in stock); Michael M. Phillips et. al., Paulson Takes Lead Amid Crisis, WALL ST. J., Mar. 22, 2008, at A4 (reporting that Treasury Secretary Paulson urged Fannie and Freddie to raise some ten billion dollars each in new capital and boost number of mortgages they could finance). Concerns over the solvency of Fannie and Freddie led Standard \& Poor's to issue a report suggesting that the implicit government guarantees of Fannie and Freddie could cause the United States to lose its triple-A rating if the federal government had to bail out the two companies. See Prabha Natarajan, Fannie, Freddie Could Hurt U.S. Credit, WALl ST. J., Apr. 15, 2008, at C2.

50. "Safety and soundness" regulation refers to government oversight of financial institutions to ensure that they are adequately capitalized given their exposure to risk and given the negative externalities that their failure would cause. See Mark J. Flannery, Supervising Bank Safety and Soundness: Some Open Issues, 92 ECON. R. 83, 86 (2007).

51. See Krishna Guha et al., Saviours of The Suburbs, FIN. TIMES, June 4, 2008, at 1 (noting that Fannie and Freddie's current performance is making the possibility of a bailout more likely); James R. Hagerty et. al., Fannie, Freddie Called Weak in Capital Base, WALL ST. J., May 17, 2008, at A3 (reporting that OFHEO Director James Lockhart charges that Fannie and Freddie are at "point of vulnerability" due to lack of capital); James R. Hagerty, U.S. Mulls Future of Fannie, Freddie, WALL ST. J., July 10, 2008, at Al (noting that Fannie and Freddie's recent financial performance has intensified Bush Administration talks about possibility of the need for government support of the two entities); Damian Paletta, Senate Strikes Housing Rescue Deal, WALl St. J., May 20, 2008, at A1 (reporting Senators Christopher Dodd and Richard Shelby have completed bipartisan plan that would overhaul supervision of Fannie and Freddie, and Bush Administration has indicated that this plan was workable).

52. See James R. Hagerty et. al., Mortgage Giants Face Pressure over Capital, WALL ST. J., July 11, 2008, at A1 (noting that if Fannie and Freddie's financial position worsens, companies could fall under conservatorship of their government regulator). 
Freddie through acquisition of its debt and equity securities; at the same time, the Federal Reserve announced that it was authorizing emergency lending to the two companies on the same terms that it had historically lent to its regulated banks and, since the Bear Stearns bailout, to primary dealers. ${ }^{53}$ The Bush Administration kept up the pressure to move the bailout plan forward, even in the face of Republican hostility in Congress based on opposition to a taxpayer bailout of the two entities. ${ }^{54}$ The bailout plan was enacted as part of the Housing and Economic Recovery Act of $2008 .^{55}$ While this gave confidence that debt-holders would be bailed out in the case of insolvency, shareholders could not feel the same way, particularly since Fannie and Freddie's massive portfolios were still in trouble.$^{56}$ It also did not offer much hope to those who had hoped that Fannie and Freddie would continue to support the housing market. ${ }^{57}$

\section{Congress Responds: The Housing and Economic Recovery Act of 2008}

The Housing and Economic Recovery Act of 2008 (the Act) was one of the major legislative responses to the credit crisis that had begun in $2007 .{ }^{58}$ Among other things, the Act revamped the regulatory oversight for Fannie and Freddie and provided the Treasury with the authority to bail out Fannie, Freddie, or both if they faced insolvency. Prior to the passage of the Act, Fannie and Freddie's financial safety and soundness regulator was OFHEO, which was an independent agency located within HUD. ${ }^{59}$ OFHEO had limited power over Fannie and Freddie to establish

53. See Krishna Guha, Fannie and Freddie Handed Roadmap, Fin. TIMES, July 14, 2008, at 2. Even these dramatic steps failed to alleviate the sense of crisis in the financial markets. Francesco Guerrera et al., Bail-out Fails To Calm Nerves, FIN. TIMES, July 15, 2008, at 1.

54. See Steven R. Weisman, Plan To Rescue Mortgage Giants Faces Resistance, N.Y. TIMES, July 16, 2008, at A1; see also Deborah Solomon, Rescue Plan Is Latest in a Series of Risks Taken on by Taxpayers, WALL ST. J., July 18, 2008, at A10 (noting that the federal government has taken on many contingent liabilities during credit crisis that could result in taxpayers being on the hook for many billions of dollars).

55. See Housing and Economic Recovery Act of 2008, Pub. L. No. 110-289, 122 Stat. 2654 (2008).

56. See Mike Ferullo, Housing Report Says GSE Holdings of Private Securities Pose Substantial Risk, 91 BANKING REP. 142 (July 28, 2008) (reporting that OFHEO stated that Fannie and Freddie subprime and Alt-A holdings continue to pose substantial risks); Mike Ferullo, Fannie, Freddie Report Unexpected Losses, Offer Grim Outlook for Housing Market, 91 BANKING REP. 216 (Aug. 11, 2008) (reporting that Fannie and Freddie had much larger-than-expected losses for the second quarter of 2008); James R. Hagerty, S\&P Cuts Some Ratings on Fannie and Freddie, WALl ST. J., Aug. 12, 2008, at C5 (noting that there is much uncertainty as to whether the federal government would protect holders of preferred stock and subordinated debt even if they were to back the companies' senior debt).

57. See Aparajita Saha-Bubna \& Prabha Natarajan, Fannie Cuts Support for Mortgage Market, WALl ST. J., Aug. 9, 2008, at B6 (reporting that Fannie Mae disclosed that it would slow its purchases of mortgage-related securities to preserve capital).

58. See Housing and Economic Recovery Act of 2008, supra note 55.

59. Federal Housing Enterprises Financial Safety and Soundness Act of 1992, 12 U.S.C. § 4501-4642 (2006). 
capital standards, ${ }^{60}$ conduct financial examinations, determine capital levels, and appoint conservators. ${ }^{61}$

Two provisions of the Act are most relevant here: (1) one that strengthens Fannie and Freddie's financial safety and soundness regulation and (2) one that temporarily increases government support for the two companies.

\section{Improved Financial Safety and Soundness Regulation}

The Act replaces OFHEO with a new independent Federal Housing Finance Agency (the Agency). ${ }^{62}$ The Agency has general regulatory authority over the two companies and the Federal Home Loan Banks. The Agency's role mirrors that of OFHEO but grants it significantly more power to regulate financial safety and soundness issues. The Agency is intended to be a top-notch financial regulator along the lines of Federal Deposit Insurance Corporation. ${ }^{63}$

The Agency is run by a Director appointed by the President with the advice and consent of the Senate. ${ }^{64}$ The Director's mandate is to ensure that both entities operate with sufficient capital and internal controls, with a mind towards the public interest, such that Fannie and Freddie accomplish their purpose of providing liquidity to the mortgage markets. ${ }^{65}$ The

60. See id. \$\$ 4611-4617; LORETTA NOTT \& BARBARA MiLES, GSE REGULATORY REFORM: FREQUENTLY ASKED QUESTIONS 5 (CRS CONG. REP. RS21724, Updated Jan. 5, 2009), available at http://assets.opencrs.com/rpts/RS21724_20090105.pdf ("Unlike OFHEO, the FHFA has the authority to modify [Fannie and Freddie's capital] standards by regulation, which allows capital requirements to be adjusted to reflect changes in perceived risk."); Reiss, supra note 2, at 1033-36 (reviewing powers of OFHEO).

61. See 12 U.S.C $\$ \$ 4611-4617$.

62. See Housing and Economic Recovery Act of 2008, supra note 55, § 1101; see also id. $\S 1301$ (abolishing OFHEO); id. $\$ 1311$ (abolishing the Federal Housing Finance Board, which regulates Federal Home Loan Banks).

63. See National COUNSEl of State Housing AgEnCIES, NCSHA SumMary of THe Housing AND ECONOMIC RECOVERY ACT OF 2008 (2008), available at http://www.ncsha.org/resource/ncshasummary-housing-and-economic-recovery-act-2008.

64. Housing and Economic Recovery Act of 2008, supra note 55, $\$ 1312$. Until the first Director is appointed, the Director of OFHEO shall serve as the Director of the Agency. See id. $\$ 1312$ (b)(5).

65. See Housing and Economic Recovery Act of 2008, supra note 55, $\S 1102$ (amending $\S 1313$ of The Federal Housing Enterprises Financial Safety and Soundness Act of 1992, 12 U.S.C. $\$ 4513$ ). The Director shall exercise his or her powers as follows: the Director shall require each enterprise to obtain the approval of the Director for any product of the enterprise before initially offering the product. See id. $\$ 4541$ (requiring that "upon receipt of a request for approval of a product . . . the Director shall publish notice of such request and of the period for public comment"). HUD previously had the power to approve new products. See id. $\S 4542$. HUD was not particularly effective in exercising it. A Fannie and Freddie regulator, then-Assistant Secretary for Housing John Weicher, testified that he "sometimes learns about new GSE programs by reading about them in the newspaper." MORTGAGE BANKERS ASSOCIATION, WHY THE BRIGHT LINE HELPS MORTGAGE MARKETS 6 (2005), available at www.mortgagebankers.org/documents/newslink/letters/BrightLineRebuttal. The Director may require regular reports from the entities regarding their operations and financial conditions. See Housing and Economic Recovery Act of 2008, supra, $\S 1104$ (amending $\$ 1314$ of the Federal Housing Enterprises Financial Safety and Soundness Act of 1992, 12 U.S.C. $\S 4514$ ). OFHEO had comparable powers, 
Director is assisted in his duties by the Federal Housing Finance Oversight Board, which advises the Director about strategies and policies. ${ }^{66}$ In addition to the Director, the Board includes the Secretary of the Treasury, the Secretary of Housing and Urban Development, and the Chairman of the Securities and Exchange Commission. ${ }^{67}$

The Act addresses the possible actions to be taken by the Agency should Fannie, Freddie, or both become undercapitalized, significantly undercapitalized, or critically undercapitalized. ${ }^{68}$ An undercapitalized entity falls under greater monitoring and restriction of activities. ${ }^{69}$ A significantly undercapitalized entity may have its board replaced or its executive officers fired. ${ }^{70}$ This is also grounds to withhold executive bonuses. ${ }^{71} \mathrm{~A}$

although the Agency now has the power to assess significant penalties for noncompliance. Compare 12 U.S.C. $\$ 4514$ (2008) with 12 U.S.C. $\$ 4514$ (2007). The Director will establish risk-based capital requirements for the enterprises to ensure that the enterprises operate in a safe and sound manner, maintaining sufficient capital and reserves to support the risks that arise in the operations and management of the enterprises. See Housing and Economic Recovery Act of 2008, supra, $\$ 1110$ (amending $\S 1361$ of the Federal Housing Enterprises Financial Safety and Soundness Act of 1992, 12 U.S.C. $\S 4611$ ). OFHEO had similar powers. Compare 12 U.S.C. $\S 4611$ (2008) with 12 U.S.C. $\S 4611$ (2007). Prior to the passage of the Act, it was generally thought that Fannie and Freddie's capital requirements were too low when compared to those of other financial institutions. See, e.g., James R. Hagerty et al., Mortgage Giant Freddie Mac Considers Major Stock Sale-Issue of Up to \$10 Billion Would Aim To Stave off Rescue Plan, WALL ST. J., July 18, 2008, at A1 (reporting that Freddie Mac's capital was low "compared with the requirements placed on other financial institutions"); James R. Hagerty \& Damian Paletta, Empowered Official Will Regulate Mortgage Giants, WALL ST. J., July 25, 2008, at A12 ("Current law sets minimum capital requirements for Fannie and Freddie at levels that appear low in relation to the recent losses caused by a surge in foreclosures and falling home prices."); Reforming the Regulation of the Government Sponsored Enterprises: Hearing Before the Senate Comm. on Banking, Housing and Urban Affairs, 110th Cong. 5 (2008) (statement of James B. Lockhart III, Director, OFHEO), available at http:/www.fhfa/gov/webfiles/1453/2708lockhart.pdf (noting that Fannie's capital requirements "are low compared to other financial institutions"). The Director will establish annual housing goals, effective from 2010 onwards, with respect to the mortgage purchases by the enterprises. See Housing and Economic Recovery Act of 2008, supra, \$\$ 112829 (amending section 1331 to Federal Housing Enterprises Financial Safety and Soundness Act of 1992 (12 U.S.C. $\$ 4561$ ) ("[F]ailing to meet goals set by the Agency may result in penalties imposed by the Director"); id. $\$ 1129$ (amending section 1335 Federal Housing Enterprises Financial Safety and Soundness Act of 1992, 12 U.S.C. $\S 4565$ ). This amendment transfers the authority for setting affordable housing goals from HUD to the Agency.

66. See Housing and Economic Recovery Act of 2008, supra note 55, §1103 (codified at 12 U.S.C. \& 4513a).

67. Id. The Agency also has an Inspector General authorized to hire accountants and economists to review the financial health of the two companies. See id. $\S 1105$ (amending $\$ 1317$ of the Federal Housing Enterprises Financial Safety and Soundness Act of 1992, 12 U.S.C. $\$ 4517$ ). The operating costs of the Agency will be borne by annual assessments on Fannie and Freddie that are set by the Agency. See id. $\S 1106$. While OFHEO's funding mechanism was also based on assessments of the two companies, it required Congressional appropriations approval, which made OFHEO more susceptible to political influence. Compare 12 U.S.C. $\$ 4516(f)(2008)$ with 12 U.S.C. $\S 4516(f)(2007)$.

68. See Housing and Economic Recovery Act of 2008, supra note 55, $\$ \S 1143-45$ (amending $\$ \$ 1365-67$ of the Federal Housing Enterprises Financial Safety and Soundness Act of 1992, 12 U.S.C. $\$ \S 4615-17)$. These amendments expand the toolkit available to the Agency in dealing with an undercapitalized Fannie or Freddie. Compare 12 U.S.C. $\$ \S 4615-17$ (2008) with 12 U.S.C. $\$$ 461517 (2007).

69. See Housing and Economic Recovery Act of 2008, supra note 55, § 1143.

70. Id. $\$ 1144$.

71. Id. The Director also has the authority to withhold executive compensation, including so- 
critically undercapitalized entity may have the Agency named as conservator or receiver. ${ }^{72}$

\section{E. Temporary Government Support}

The Act temporarily authorizes the Secretary of the Treasury to make unlimited equity and debt investments in Fannie and Freddie securities. ${ }^{73}$ This appears to be the first time that the Treasury has been authorized to invest in the equity of privately held companies. ${ }^{74}$ This will only be done by mutual agreement between the relevant GSE and the Secretary of the Treasury.$^{75}$ In order to purchase obligations, an emergency determination must be made by the Secretary of the Treasury. ${ }^{76}$ This determination must address whether such actions are necessary to provide stability to the financial markets, prevent disruptions in the availability of mortgage finance, and protect the taxpayer. ${ }^{77}$

Prior to issuing any proposed or final regulations, orders, or guidelines with respect to the exercise of the additional authority provided in the Act regarding either prudential management and operations standards or safe and sound operations for, and capital requirements and portfolio stan-

called "golden parachutes." Id. $\S 1113$ (amending $\S 1318$ (b) of the Federal Housing Enterprises Financial Safety and Soundness Act of 1992,12 U.S.C. $\S 4518$ ). OFHEO's ability to limit executive compensation was not as broad as that of the Agency. Compare 12 U.S.C. $\$ 4518$ (2008) with 12 U.S.C. $\S 4518$ (2007).

72. See Housing and Economic Recovery Act of 2008, supra note 55, § 1145. Conservatorship and receivership are quite similar, although a conservatorship is generally preferred where the entity is expected to return sound and solvent at some point in the future. See, e.g., FDIC, RESOLUTIONS HANDBOOK 70-71 (2003), available at http://www.fdic.gov/bank/historical/reshandbook/index.html. For an exploration of receivership of large commercial banks as a blueprint for any future resolution of the GSEs, see Larry D. Wall et al., Resolving Large Financial Intermediaries: Banks Versus Housing Enterprises, 1 J. FIN. STABILITY 386 (2005). The authors list institutional scale, regulatory relationship with the federal government, federal charters and exemption from the Bankruptcy Code as common traits shared by both types of entities.

73. See Housing and Economic Recovery Act of 2008, supra note 55, § 1117 (amending \& 304 of the Federal National Mortgage Association Charter Act, 12 U.S.C. $\S 1719$ ) (expiring on Dec. 31, 2009).

74. See Clyde Mitchell, Domestic Banking, N.Y.L.J., Oct. 15, 2008, at 3. Of course, this support was nothing compared to the Troubled Assets Relief Program (TARP) that Congress authorized soon thereafter. See Deborah Solomon et al., U.S. To Buy Stakes in Nation's Largest Banks-Recipients Include Citi, Bank of America, Goldman; Government Pressures All To Accept Money as Part of Broadened Rescue Effort, WALL ST. J., Oct. 14, 2008, at A1; Emergency Economic Stabilization Act of 2008, Pub. L. No. 110-343, 122 Stat. 3765 (2008) (containing TARP enabling legislation). Other instrumentalities of the federal government have, however, had the authority to purchase stakes in private companies during times of economic stress. The Reconstruction Finance Corporation, for instance, was chartered in 1932 in part to "purchase[] preferred stock, capital notes, or debentures of banks and trust companies ... . " Reconstruction Finance Corporation Act, 47 Stat. 5 (1932) (repealed 1957), available at http://www.archives.gov/research/guide-fed-records/groups/234.html\#234.1 (reflecting actual purchases of preferred stock).

75. See Housing and Economic Recovery Act of 2008, supra note 55, § 1117.

76. See id.

77. See id. (amending $\$ 304$ of the Federal National Mortgage Association Charter Act, 12 U.S.C. $\S 1719$, by adding 12 U.S.C. $\$ 1719(\mathrm{~g})$ ). 
dards applicable to, Fannie and Freddie, the Director must consult with, and consider the views of, the Chairman of the Board of Governors of the Federal Reserve System with respect to the risks posed by the regulated entities to the financial system. ${ }^{78}$

In addition to the two provisions discussed above, the Act has two more that are of some importance to this Article. These two provisions relate to how the two firms seek to expand their market share and how they engage in political horse-trading to achieve their ends, which relate to the argument in favor of privatization set forth in Part III below. The first provision provides funding for affordable housing through an assessment on Fannie and Freddie. The second provision increases the conforming loan limits. This increase expands the companies' market and increases the availability of mortgage credit during the crisis.

The Act requires that Fannie and Freddie "set aside an amount equal to 4.2 basis points for each dollar of the unpaid principal balance of its total new business purchases." ${ }^{\prime 7}$ When the Act was passed, it was generally agreed that this provision would raise upwards of $\$ 500$ million each year for affordable housing initiatives. ${ }^{80}$

The Act also raises the conforming loan limits in some areas. Such limits shall be increased in areas for which $115 \%$ of the median house price exceeds the conforming loan limits to the lesser of $150 \%$ of such loan limit or the amount that is equal to $115 \%$ of the median house price in such area. ${ }^{81}$

\section{F. Fannie and Freddie Enter Conservatorship}

Within days of the passage of the Housing and Economic Recovery Act, Fannie and Freddie faced demands to raise more capital-pressures that they would not be able to meet. ${ }^{82}$ Within a few weeks, the markets were expecting the federal government to bail out the two companies. ${ }^{83}$ And within a couple of months, Paulson announced that he was placing the two companies in conservatorship because they were not able to raise the

78. Id. $\S 1118$ (amending section 1313(a) of the Federal Housing Enterprises Financial Safety and Soundness Act of 1992, 12 U.S.C. $\S 4513$ ). This requirement expires on December 31, 2009. Id.

79. 12 U.S.C. $\$ 4567(\mathrm{a})(1)(\mathrm{A})(2008)$.

80. See Elizabeth Williamson \& Brody Mullins, Democratic Ally Mobilizes in Housing Crunch, WALL ST. J., July 31, 2008, at A1 (estimating $\$ 600$ million); David M. Herszenhorn, Approval Is Near for Bill To Help U.S. Homeowners, N.Y. TiMES, June 25, 2008, at A1 (estimating $\$ 500-\$ 900$ million). It is unclear what the impact of Fannie and Freddie's entering into conservatorship will have on this provision.

81. See Housing and Economic Recovery Act of 2008, supra note 55, $\$ 1124$ (amending $\S 302$ (b)(2) of the Federal National Mortgage Association Charter Act, 12 U.S.C. $\$ 1717$ (b)(2)). The conforming loan limit is adjusted annually. See id.

82. See Hagerty et al., supra note 52, at A1.

83. See James R. Hagerty \& Aparajita Saha-Bubna, Fannie Mae, Freddie Mac Are Pounded-Two Stocks Plunge on Growing Fears of a U.S. Bailout, WALL ST. J., Aug. 19, 2008, at A3. 
capital they needed to continue operating ${ }^{84}$ Throughout the credit crisis, their reported losses have only continued to increase. ${ }^{85}$

One important consequence of conservatorship is its impact on the implied guarantee. Some commentators argue that the implied guarantee is now an explicit one. ${ }^{86}$ The government and the market have not yet embraced this view. ${ }^{87}$ How the two companies exit their conservatorships will determine the nature of such guarantee as well.

As the credit crisis unfolds, there is much speculation as to what form Fannie and Freddie should take upon exiting conservatorship once the credit crisis has passed. Part II proposes a theoretical framework to help determine the answer to that question.

\section{EVALUATING FANNIE AND FREDDIE}

There is very little controversy over the overwhelming benefits that Fannie and Freddie brought to the national mortgage market during the 1970s; indeed, they, along with Ginnie Mae, effectively created it ${ }^{88}$ But at least since the early 1990s, there has been much disagreement with Fannie and Freddie's claims that they continue to provide overwhelming benefits

84. See James R. Hagerty et al., U.S. Seizes Mortgage Giants-Government Ousts CEOs of Fannie, Freddie; Promises up to $\$ 200$ Billion in Capital, WALL ST. J., Sept. 8, 2008, at A1.

85. See James R. Hagerty \& Damian Paletta, Red Ink Clouds Role of Fannie, Freddie, WALL ST. J., Feb. 27, 2009, at A2 (reporting $\$ 59$ billion loss for Fannie in 2008 and comparable losses for Freddie on the horizon).

86. See Peter J. Wallison, Fannie and Freddie by Twilight, FIN. SERVICES OUTLOOK 1 (Aug. 2008) (describing post-Act Fannie and Freddie as "explicitly government-backed entities").

87. Spreads for Fannie and Freddie securities still reflect a market belief that there is no explicit guarantee. See, e.g., Congressional Budget Office (CBO), CBO's Estimate of Cost of the Administration's Proposal To Authorize Federal Financial Assistance for the Government-Sponsored Enterprises for Housing (July 22, 2008) ("Although the GSEs are currently publicly traded shareholder-owned firms, the legislation would at least temporarily strengthen the connections between the GSEs and the federal government."); Prabha Natarajan, Fed Begins Buying Mortgage Bonds-Action Taken to Lower Rates for Homeowners; Risk Premiums Narrow Further, WALL ST. J., Jan. 6, 2009, at C3 (reporting that risk premium for Fannie and Freddie securities were high but were being narrowed by Federal Reserve purchases); James R. Hagerty, U.S. Rethinks Roles of Fannie, Freddie, WALL ST. J., Dec. 1, 2008 , at A5 (outlining options to provide explicit federal guarantee of Fannie and Freddie obligations); Jody Shenn, Fannie Guarantee Won't Cut Debt Costs, Lockhart Says, BloomBerg News, Dec. 30, 2008, http://www.bloomberg.com/apps/news?pid=newsarchive\&sid=abaRWfI1R9vY (reporting that Federal Housing Finance Agency Director James Lockhart denies existence of explicit federal guarantee); but see The Present Condition and Future Status of Fannie Mae and Freddie Mac, Before the Subcomm. on Capital Markets, Insurance, and Government-Sponsored Enterprises of the H. Fin. Services Comm, 111th Cong. 3 (2009) available at http://www.house.gov/apps/ list/hearing/ financialsvcs_dem /hrcm060309.shtml [hereinafter Subcomm. on Capital Markets, Insur. and GovernmentSponsored Enterprises (2009)] (prepared statement of James B. Lockhart, III, Director of the Fed. Housing Fin. Agency) (Lockhart identifies the federal government's "effective guarantee" of the GSEs' debt obligations).

88. See, e.g., Jay Cochran, III \& Catherine England, Neither Fish nor Fowl: An Overview of the Big-Three Government-Sponsored Enterprises in the U.S. Housing Finance Markets 1 (Mercatus Ctr., Working Papers in Regulatory Studies, 2001), available at http://www.mercatus.org/uploadedFiles/ Mercatus/Publications/MC_RSP_RP-FishNorFowl_011115.pdf. 
to America's homeowners. ${ }^{89}$ There has also been an exploration of the costs that the two companies impose on the American government and on the mortgage markets. This Part begins by reviewing how Fannie and Freddie claim to benefit the residential housing finance market and how "independent scholars" ${ }^{\prime 0}$ evaluate their success at reaching these goals. It then draws on theories of regulation and monopoly to propose a more comprehensive mode of evaluation, which untangles their hybrid public/private structure to demonstrate how that structure gives them extraordinary benefits that undercut competition in the mortgage markets as well as their statutorily mandated public missions.

\section{A. Fannie and Freddie's Self-Assessment}

Fannie and Freddie set forth four standards by which they believe they should be judged: (1) they lower overall interest rates for homeowners, (2) they offer systemic stability and liquidity to the market, (3) they increase the supply of affordable housing, and (4) they have increased consumer protection in the residential market. I will review evidence for each of these claims in turn. I find that independent research challenges some of these claimed benefits. Moreover, these four standards are ad hoc and fail to account for many other impacts that the two companies have on the housing market.

\section{Lower Overall Interest Rates for Homeowners}

Fannie and Freddie claim that they lower interest rates for homeowners. There is nearly universal agreement that this is true. While Fannie and Freddie describe these lower rates as significant, independent scholars describe them as modest.

Various studies have measured the benefit to conforming borrowers as being between 24 and 43 basis points. ${ }^{91}$ Assuming an increased 34 point

89. See, e.g., STANTON, supra note 27; see also Carnell, supra note 2, at 587 (2005) ("The GSEs imply that these market improvements depend on GSEs' continued government sponsorship, as if the old defects would recur if GSEs lost their subsidies.").

90. Fannie and Freddie have funded, directly or indirectly, most of the research that pertains to them. That research typically supports Fannie and Freddie's own agendas. In addition, many of the scholars writing about Fannie and Freddie have worked or do work for one of the two companies. Again, much of their research is supportive of the two companies. I use the terms "independent scholars" and "independent research" to distinguish scholarly work produced by those without a connection to the two firms as well as research by Fannie- or Freddie-affiliated researchers that does not appear to have a pro-Fannie and Freddie bias.

91. James E. Pearce \& James C. Miller III, REvisiting the Net Benefits of Freddie MAC AND FANNIE MAE 16 (2006) available at http://www.freddiemac.com/ corporate/reports/pdf/2006\% 20Pearce\%20 Miller\%20 report.pdf. There is a strong argument that the beneficiaries of this reduction in interest rates are not home buyers, but rather developers and home sellers, as the "lower rates attributable to the GSEs' subsidized borrowing are simply capitalized into the cost of the homes . . .." Peter J. Wallison \& Bert Ely, Nationalizing MoRTGAGE RisK: THE GrowTH of FANNIE MAE AND 
spread (halfway between the two figures) on a $\$ 200,000$ mortgage, a borrower would pay an additional $\$ 57$ a month in interest. ${ }^{92}$ This figure, while significant for the average American homeowner, is not an extraordinary benefit, particularly for those who can itemize their home mortgage interest deduction to further reduce the after-tax bite of such interest payments.

Moreover, Michael Froomkin identifies a hidden cost that the Fannie and Freddie financing model imposes: in many ways the federal government is borrowing at a higher cost than it needs to if it wants to subsidize residential mortgages. ${ }^{93}$ Instead of borrowing through a GSE, the federal government could act directly at a lower cost to assist favored constituencies like homeowners. For instance, the federal government could directly provide or guarantee certain kinds of mortgages at a cheaper cost than Fannie and Freddie, much like it directly provides student loans at a cheaper cost than private educational lenders. ${ }^{94}$ This hidden cost has come into sharper relief during the current credit crisis, when Fannie and Freddie's borrowing costs remained for quite some time stubbornly high, even after they entered conservatorship. ${ }^{95}$ Thus, the Fannie and Freddie model may not be the most cost-effective means by which the government can achieve the goal of lower interest rates for homeowners. ${ }^{96}$

FREDDIE MAC 5-6 (2000), available at http://www.aei.org/docLib/20040218_book173.pdf.

92. The average existing home cost a bit more than $\$ 240,000$ in 2008. Nat'l Ass'n of Realtors, Existing-Home Sales Overview Chart (2010), available at http://www.realtor.org/ wps/wcm/connect/ 08733d00446 8b958ae14f e830ed934e2/ REL1009EHS.pdf ?MOD=AJPERES\& CACHEID = 08733 d004468b958ae14fe830ed934e2. Assuming a 20\% down payment, the average mortgage for such a home would be roughly $\$ 200,000$.

93. See Michael Froomkin, Reinventing the Government Corporation, 1995 U. ILL. L. REV. 543, 616-17 (1995).

94. See Robert Shireman, What School Loan Scandal?, N.Y. TiMES, June 14, 2004, at A19 ("Every independent, apples-to-apples cost comparison-whether by the G.A.O., by the Congressional Budget Office or by the president's Office of Management and Budget-has shown that the direct loan program is cheaper" than programs that operate through private lenders.).

95. See James R. Hagerty, Mortgage Plan Isn't Cutting Rates-Borrowing Costs for Fannie Mae, Freddie Mac Are Rising Amid Debt Buyers' Jitters, WALL ST. J., Oct. 30, 2008, at A3. Spreads on Fannie and Freddie debt only began to shrink when the Federal Reserve announced that it would buy up to $\$ 600$ billion of their debt (as well as that of Ginnie Mae and the FHLBs), thereby signaling its confidence in the long-term health of the two companies. See Jon Hilsenrath \& Sudeep Reddy, Fed Signals More Action as Slump Drags on-Recession Began a Year Ago, Making It Longest Since Early '80s, Panel Says; Bernanke Considers Rate Cuts, Bond Purchases, WALL ST. J., Dec. 2, 2008, at A1.

96. One recent proposal by R. Glenn Hubbard and Christopher Mayer to resolve the credit crisis adopts this position. See Paul Milstein Center for Real Estate at Columbia Business School website, http://www4.gsb.columbia.edu/realestate/research/housingcrisis/mortgagemarket (last visited Sept. 24, 2010) (providing various documents outlining proposal to have government pass on its lower cost of funds to homeowners). 


\section{Systemic Stability and Liquidity}

Congress gave Fannie and Freddie the task of providing liquidity and stability to the secondary mortgage markets. ${ }^{97}$ In 2003, OFHEO issued a report titled "Systemic Risk: Fannie Mae, Freddie Mac and The Role of OFHEO" that evaluated their role in the broader financial markets. The report argued that the systemic implications of Fannie or Freddie's financial difficulties would depend on the circumstances: "Any systemic disruption would likely be minimal as OFHEO took prompt corrective action and other market participants filled the short-term market void. Alternatively, in the unlikely circumstance that an enterprise experienced severe financial difficulties, they could cause disruptions to the housing market and financial system." 98

While the secondary mortgage markets generally function well and without liquidity crises, the credit crunch of 2007-2009 has provided a rare opportunity to evaluate the impact of Fannie and Freddie on liquidity. At early stages in the crisis, Fannie and Freddie promoted themselves as white knights and lobbied for access to a broader swath of the mortgage market in order to stabilize them. ${ }^{99}$ But as the credit crisis developed, it became clear that Fannie and Freddie were subject to the same forces that had led to the insolvency and massive write-downs of private mortgage lenders, until the government stepped in quite forcefully to bolster the government-supported mortgage market. ${ }^{100}$

97. See 12 U.S.C. $\$ 1716$ (2006). The Office of Management and Budget has said that "GSEs were created because wholly private financial institutions were believed to be incapable of providing an adequate supply of loanable funds at all times and to all regions of the nation for specified types of borrowers." Memorandum from Alice M. Rivlin, Office of Management and Budget, to Heads of Executive Departments and Agencies Establishing Specifications for Creating Government Corporations (M-96-05), App. I at 14 (Dec. 8, 1995) [hereinafter "Memorandum for Heads of Executive Departments and Agencies"], available at http://www.whitehouse.gov/ sites/default/files/omb/assets/ omb/memoranda /m96-05.pdf.

98. OFHEO, SySTEMIC Risk: FANNIE MAE, FREdDIE MAC AND THE ROLE OF OFHEO 1 (2003) available at http:/fhfa.gov/webfiles/1145/sysrisk.pdf; see also Paul Kupiec \& David Nickerson, Assessing Systemic Risk Exposure from Banks and GSEs Under Alternative Approaches to Capital Regulation, 28 J. REAL EST. FIN. \& ECON. 123 (2004) (arguing, in this paper co-authored by a Freddie Mac consultant, that lower capital requirements like those of Fannie and Freddie can reduce systemic risk); Robert Seiler, Fannie Mae and Freddie Mac as Investor-Owned Utilities, 11 J. PuB. BuDGETING ACCT. \& FIN. MGMT. 117, 118 (1999) (arguing that, because of implied guaranty, GSEs have "an incentive to increase its risk exposure and leverage in a search for higher profits for owners.").

99. See Eric Dash, Fannie Mae's Offer To Help Ease Credit Squeeze Is Rejected, as Critics Complain of Opportunism, N.Y. TIMES, Aug. 11, 2007, at C1.

100. See Ruth Simon, Homeowners' Refinancing Jumps By Record Pace, WALL ST. J., Dec. 4, 2008, at $\mathrm{C} 1$; see also ThOMAS H. STANTON, GovernMENT-SPONSORED ENTERPRISES: MERCANTILIST COMPANIES IN THE MODERN WORLD 39 (2002) (noting that GSE specialization "removes a form of diversification that can help an institution absorb financial shocks."). In testimony before the Senate in 2005, then-Federal Reserve Chairman Alan Greenspan warned that the GSEs" large portfolios, far from creating a liquidity buffer against a market crisis as some GSE-insiders argued, were in fact the major source of GSE-related systemic risk. See Reform of the Government 
In early 2008, the federal government authorized Fannie and Freddie to purchase loans with significantly higher principal amounts in high-cost areas like New York and California, again in order to provide additional liquidity ${ }^{101}$ But at around the same time, Fannie and Freddie revealed that they faced billions of dollars in losses caused by their poor underwriting. ${ }^{102}$ Fannie Mae issued additional shares to raise billions of dollars of capital to ensure that they complied with OFHEO capitalization requirements and Freddie Mac planned to do the same. ${ }^{103}$ But, as noted above, Fannie and Freddie ultimately required a bailout in order to prevent a crisis that would have spread far beyond the American residential mortgage market to infect the entire global credit market, if left unchecked. ${ }^{104}$ The net effect is that Fannie and Freddie did provide some temporary liquidity and stability. But their long-term impact was very harmful to the broad financial system, and it will likely cost the American taxpayer tens of billions of dollars to resolve the harm they ultimately caused.

\section{Affordable Housing Goals}

The Federal Housing Enterprises Financial Safety and Soundness Act of 1992 established three affordable housing goals for Fannie and Freddie: ${ }^{105}$ those for (1) low- and moderate-income housing; (2) special affordable housing; and (3) central cities, rural areas, and housing in other under-served areas. ${ }^{106}$ Pursuant to this statute, HUD is responsible for moni-

Sponsored Enterprises Before the S. Comm. on Banking, Housing and Urban Affairs, 109th Cong. 5-8 (2005) (prepared statement of Alan Greenspan, Chairman, Federal Reserve System). Harvard's Joint Center for Housing Studies argues that the GSEs provided market liquidity through credit crunches in 1998 and 2001. See JoInT CTR. FOR Housing Studies OF Harvard UnIV., MEETING Multifamily FinANCE NeEdS DURING AND AFTER THE CREDIT CRISIS: A POLICY BRIEF 11-12 (2009) [hereinafter MeEting Multifamily Finance NeEds During AND AFTer the Credit Crisis], http:// www.jchs.harvard.edu/ publications/ finance/ multifamily_housing finance_needs.pdf. While I acknowledge that the GSEs did provide limited liquidity relief, the Center fails to account for the hundreds of billions of dollars that the bailout may ultimately cost, as well as the additional systemic risk that the insolvency of the two entities had imposed on the financial system in 2008.

101. See note 45 and accompanying text.

102. See James R. Hagerty \& Andrew Edwards, Fannie Mae Lowers Housing Outlook as It Logs $\$ 3.56$ Billion Loss, WALl ST. J., Feb. 28, 2008, at A2; James R. Hagerty \& Aparajita Saha-Bubna, Credit Crunch: Freddie Posts Big Loss but Has Enough Capital, WALL ST. J., Feb. 29, 2008, at C2.

103. See Hagerty et al., supra note 65 (reporting that by May 2008, "Fannie had raised $\$ 7.4$ billion of capital by selling common and preferred shares.").

104. See Hagerty et al., supra note 84, at A1 (quoting Treasury Secretary Paulson as stating that "[f]ailure of either of them would cause great turmoil in our financial markets here at home and around the globe."); see also supra Part I.D.

105. See 12 U.S.C. $\$ 4501$ et seq. (2008). These goals would have also been affected by the Housing and Economic Recovery Act of 2008's affordable housing fund, if the two companies had not entered conservatorship. See supra notes 65 and 79. See also FEDERAL NATIONAL MORTGAGE Association, Form 8-K (Nov. 12, 2008), available at http://www.sec.gov/Archives/edgar/data/ 310522/000129993308005442/htm_30041.htm (reporting that the Agency has suspended Fannie's contributions to affordable housing fund under the Act).

106. See 12 U.S.C. $\$ \S 4562-64$. The low-and moderate-income housing goal targets "families with 
toring, adjusting, and enforcing these housing goals. ${ }^{107}$ These goals represent what should be the minimum percentage of housing units financed by Fannie and Freddie each year. ${ }^{108}$

Fannie and Freddie typically meet these goals, although they sometimes may use financing shenanigans (such as buying a portfolio of loans solely to meet affordable housing goals) to do so. ${ }^{109}$ Independent research, however, has challenged whether these goals actually increase the net amount of affordable housing. A number of studies have indicated that Fannie and Freddie actually cannibalize the Federal Housing Administration (FHA) loan market by lending to borrowers who would have otherwise received FHA mortgages. ${ }^{110}$ The U.S. General Accounting Office has also questioned whether Fannie and Freddie, notwithstanding their affordable housing mandate, do any more than any other lenders to promote affordable housing. ${ }^{111}$

incomes at or below the area median income"; the special affordable housing goal targets families at or below $60 \%$ of area median income, as well as low-income families in low-income areas which areas are at or below $80 \%$ of area median income; and the underserved areas housing goal targets families "living in low-income census tracts or in low- or middle-income census tracts with high minority populations." HUD, HUD Regulation of Fannie Mae and Freddie Mac, available at http:// web.archive.org/ web/ 20070911170002/ www.hud.gov/ offices/ hsg/ gse/ gse.cfm [hereinafter HUD Regulation]. See generally 24 C.F.R. $\$ \$ 81.11-81.22$ (2010) (setting forth Fannie and Freddie's housing goals).

107. See 12 U.S.C. $\$ \$ 4561$ (adjusting) and 4566 (monitoring and enforcing).

108. HUD Regulation, supra note 106. HUD issued a series of notices and regulations setting these goals for a transition period and beyond. $I d$.

109. See James R. Hagerty, Fannie, Freddie Face a Tough Plan-Senate Republicans Offer Strong Bill to Strengthen Mortgage Firms' Oversight, WALL ST. J., Mar. 29, 2004, at A2 (reporting that HUD was investigating transaction between Freddie and Washington Mutual Inc. (WaMu), in which Freddie "bought $\$ 6$ billion of mortgages on multifamily housing units from WaMu to help Freddie meet its affordable-housing goals for 2003"); John D. McKinnon \& John R. Wilke, HUD Says Freddie Double-Counted Some Transactions, WALL ST. J., Oct. 15, 2004, at A2 (reporting that Freddie failed to meet affordable housing goal).

110. See Xudong An \& Raphael W. Bostic, GSE Activity, FHA Feedback, and Implications for the Efficacy of the Affordable Housing Goals 5-6, 18 (USC Lusk Center for Real Estate Working Paper 2006-1005) (Feb. 13, 2006), available at http:// www.usc.edu/ schools/sppd/ lusk / research/ pdf/ wp_2006-1005.pdf (reviewing research that finds that Fannie and Freddie have responded positively to their affordable housing goals, but finding that those goals and goals of FHA "work in opposite directions and can leave credit supply and homeownership unchanged or possibly even reduced."). But see Brent W. Ambrose \& Thomas W. Thibodeau, Have the GSES Affordable Housing Goals Increased the Supply of Mortgage Credit, 34 REGIONAL SCI. \& URB. ECON. 263, 263 (2004) (finding that the affordable housing goals "increased the supply of mortgage credit available to low- and moderateincome households, after controlling for other mortgage market factors.") (both of these authors have received research funding from Fannie Mae); Roberto G. Quercia et al., The Impacts of Affordable Lending Efforts on Homeownership Rates, 12 J. HouSING ECON. 29 (2003) (Freddie Mac-funded research finding that GSE activities increase rate of homeownership, particularly among minorities); Brent Ambrose et al., ForEwORD, U.S. DEP'T OF HOUSING \& URB. DEV. (HUD), AN ANALYSIS OF THE EFFECTS OF THE GSE AFFORDABLE GoAlS ON LOW- AND MODERATE-INCOME FAMILIES (Prepared by The Urban Institute, 2002), available at http:// www.huduser.org/ Publications/ pdf/ gsegoals.pdf (finding suggestive evidence that homeownership rates have "increased faster for low- and moderate-income families in areas where the GSEs have relatively large market shares.") (two of these authors have received research funding from Fannie Mae).

111. See Thomas H. Stanton \& Ronald C. Moe, Government Corporations and GovernmentSponsored Enterprises, in THE ToOls of GovernMENT: A GuIdE TO THE NEW GovernanCE 80, 107 


\section{Consumer Protection}

Fannie and Freddie argue that they have helped to standardize the conforming mortgage to the benefit of consumers. ${ }^{112}$ Many, including this author, have praised this standardization as a positive, something that on the whole reduces bad options for consumers. ${ }^{113}$ This generally positive development is not without some costs to consumers, however, as it reduces the financing choices available to them. For instance, Fannie and Freddie have effectively banished prepayment penalties from the prime conforming mortgage market, which sounds like a good thing for consumers. ${ }^{114}$ But some consumers might have preferred to take a loan with a prepayment penalty if it meant that the loan would have a lower interest rate. ${ }^{115}$

n.56 (2002) (Lester M. Salamon ed., 2002) (citing U.S. General Accounting Office, Federal Housing Enterprises: HUD's Mission Oversight Needs To Be Strengthened, GAO/GGD 98-173 (1998)); see Richard A. Williams et al., The Effects of the GSES, CRA, and Institutional Characteristics on Home Mortgage Lending to Underserved Markets, 5 CITYSCAPE 9 (2001), available at http://www.huduser.org/ Periodicals/CITYSCPE/VOL5NUM3/williams.pdf (studying the impact of various housing factors in 1990's Indiana, and noting that the GSEs were not leading but mirroring the private market in efforts to provide financing to low- to moderate-income households); Kirk McClure, The Twin Mandates Given to the GSEs: Which Works Best, Helping Low Income Homebuyers or Helping Underserved Areas? 5 Cityscape 107 (2001), available at http://www.huduser.org/ Periodicals/CITYSCPE/VOL5NUM3/mcclure.pdf (finding similar results in the Kansas City area during the 1990s); STANTON, supra note 100, at 81 ("HUD has informed Congress that its analysis of HMDA data] shows that both GSEs continue to lag the rest of the market in funding affordable housing loans for lower-income families and in under-served communities."). In the area of multifamily mortgage finance, the GSEs have not been perceived as leaders either. See KIMBERLY BURNETT \& LINDA B. FosbuRG, STUdy OF THE MULTIFAMILY UNDERWRITING AND THE GSES' ROLE IN THE MULTIFAMILY MARKET: EXPANDED VERSION ix (2001) (noting that Fannie and Freddie were not seen as leaders in "affordable segments of the multifamily market"); but see Edward J. Szymanoski \& Susan J. Donahue, Do FHA Multifamily Mortgage Insurance Programs Provide Affordable Housing and Serve Underserved Areas?: An Analysis of FHA's Fiscal Year 1997 Book of Business and Comparison with the GSEs 19-20 (HUD Housing Finance Working Paper Series, HF-008, 1999) (arguing that GSEs provide affordable housing benefits comparable to FHA program).

112. See FANNIE MAE, ABOUT FANNIE MAE, available at http://www.fanniemae.com/ $\mathrm{kb} /$ index?page $=$ home $\& \mathrm{c}=$ aboutus (last visited Sept. 24, 2010); FrEDDIE MAC, OUR MISSION, http://www.freddiemac.com/corporate/company_profile/our_mission (last visited Sept. 24, 2010).

113. See Peter M. Carrozzo, Marketing the American Mortgage: The Emergency Home Finance Act of 1970, Standardization and the Secondary Market Revolution, 39 REAL PROP. PROB. \& TR. J. 765 (2005); Julia Patterson Forrester, Fannie Mae/Freddie Mac Uniform Mortgage Instruments: The Forgotten Benefit to Homeowners, 72 Mo. L. REV. 1077 (2007); Raymond A. Jensen, Mortgage Standardization: History of Interaction of Economics, Consumerism and Governmental Pressure, 7 REAL PROP. PROB. \& TR. J. 397, 400 (1972) (noting that Fannie Mae created a task force to identify "substantive mortgage clauses which would be essential to make the [uniform form of] mortgage saleable to investors"); David Reiss, Subprime Standardization: How Rating Agencies Allow Predatory Lending To Flourish in the Secondary Mortgage Market, 33 FLA. ST. U. L. REV. 985, 1056 (2006).

114. See Freddie Mac, Frequently Asked Questions on Prepayment Penalties, available at http://web.archive.org/web/20061211130629/www.freddiemac.com/singlefamily/ppmqanda.html (last visited Oct. 1,2010 ) (noting that only $2 \%$ of prime market loans have prepayment penalties).

115. It is a question of policy as to which of these states of affairs is better for consumers, and one that will not be reached here. See Lauren E. Willis, Decisionmaking and the Limits of Disclosure: The Problem of Predatory Lending: Price, 65 MD. L. REV. 707, 741-54 (2006) (reviewing and critiquing "rational actor" model in context of residential mortgage market consumer). 
Moreover, recent news about Freddie's role in the subprime and AltA markets undercut Fannie and Freddie's consumer protection argument to some extent. ${ }^{116}$ Apparently, the two firms had a much greater exposure to the disastrous Alt-A subsector than they had previously let on. ${ }^{117}$ In Congressional testimony in late 2008, Fannie's former chief credit officer reported that the two companies "now guarantee or hold 10.5 million nonprime loans worth $\$ 1.6$ trillion-one in three of all subprime loans, and nearly two in three of all so-called Alt-A loans, often called "liar loans." " 118 As these two sectors were rife with predatory lending practices, Fannie and Freddie may be seen as complicit with these practices even though they did not engage in them directly.

\section{B. Existing Theories of the Government-Sponsored Enterprise}

Alice Rivlin, as then-director of the Office of Management and Budget, has stated that "GSEs were created because wholly private financial institutions were believed to be incapable of providing an adequate supply of loanable funds at all times and to all regions of the nation for specified types of borrowers." ${ }^{119}$ This is certainly the primary reason that Congress employs GSEs, even if, as Thomas Stanton notes, "market imperfections are much more difficult to find today" than they were when Fannie and Freddie were created. ${ }^{120}$

Michael Froomkin has suggested four additional reasons behind Congress's decision to create federal government corporations like Fannie and Freddie: (a) they are believed to be more efficient at achieving marketrelated goals, (b) they are believed to be more insulated from politics than a division of a large federal agency, (c) they are believed to be effective at delivering targeted subsidies, and (d) they are a useful subterfuge for Congress because their borrowing is typically not counted as part of the federal deficit. ${ }^{121}$ As seen in this Article, there is good reason to doubt that the

116. See Floyd Norris, Can Lenders Suddenly Tighten Reins?, N.Y. TIMES, Mar. 2, 2007, at C1 (reporting that Freddie Mac announced that it would pull back from the riskier part of the subprime market, which it claimed that it entered in part to meet its affordable housing goals, because it was funding many mortgages that were ultimately defaulting).

117. See James R. Hagerty, Fannie, Freddie Executives Knew of Risks, WaLl ST. J., Dec. 10, 2008 , at A2.

118. Lynnley Browning, Ex-Officer Faults Mortgage Giants for "Orgy" of Nonprime Loans, N.Y. TIMES, Dec. 10, 2008, at B3.

119. Office of Management and Budget, Memorandum for Heads of Executive Departments and Agencies, supra note 97, at 14; see also Stanton \& Moe, supra note 111, at 98-99 (identifying criteria for design of well-functioning GSE).

120. STANTON, supra note 100 , at 10 .

121. See Froomkin, supra note 93, at 557-59. The category of federal corporations is broader than the category of GSEs. Because of the requirements of various budget-reduction statutes in effect at various times over the last few decades, off-budget activities undertaken by GSEs were popular with Congress. See id. at 559; see also AlLEN SCHICK \& FElix LoSTRACCO, The FEdERAL Budget: POLITICS, POLICY, PROCESS 146-48 (2000) (describing impact on Congressional behavior of PAYGO 
first three reasons are as compelling as Congress would have liked. There is also good reason to believe that Congress was spot-on regarding the fourth. ${ }^{122}$ Rivlin and Froomkin outline the major reasons that Congress creates GSEs, but they do not offer a comprehensive theory of the GSE. Existing efforts to do so are reviewed below.

Finance and economics scholars have proposed a variety of cost/benefit frameworks with which to evaluate Fannie and Freddie, although this is no mean task. ${ }^{123}$ These frameworks have often relied upon various ad hoc metrics, such as whether Fannie and Freddie actually lower interest rates for homeowners or how much of the Fannie/Freddie subsidy is passed on to homebuyers. There is general agreement that the two companies do lower interest rates to some extent and that they do so by passing on a portion of the subsidy that derives from the government's guarantee of their obligations on to homeowners. ${ }^{124}$

Fannie and Freddie, of course, argue that they still provide an array of benefits, while others vigorously dispute this claim. ${ }^{125}$ Fannie and Fred-

rules prescribed by the Budget Enforcement Act of 1990, which requires offsets of the costs imposed by new legislation).

122. See infra Part III.B.

123. See Proposals for Improving the Regulation of the Housing Government Sponsored Enterprises: Hearing Before the S. Comm. on Banking, Housing, and Urban Affairs, 108th Cong. 6 (2004) (statement of Alan Greenspan, Chairman, Federal Reserve), available at http://banking.senate.gov/ public/index.cfm?FuseAction $=$ Hearings. Testimony\&Hearing_ID $=85 \mathrm{~b} 80 \mathrm{e} 9 \mathrm{~d}-3 \mathrm{edd}-4 \mathrm{~d} 91-8 \mathrm{~b} 52$ -

903e1222d7d7\&Witness ID $=0 \mathrm{~d} 3 \mathrm{c0829}-762 \mathrm{~b}-47 \mathrm{ec}-9247-70120 \mathrm{dfb} 14 \mathrm{~d} 3$ (" $[\mathrm{T}]$ he task of assessing the costs and benefits associated with the GSEs is difficult."). Cost/benefit analysis is itself not without controversy. Compare Robert H. Frank \& Cass R. Sunstein, Cost-Benefit Analysis and Relative Position, 68 U. CHI. L. REV. 323, 324 (2001) ("[T]he movement toward cost-benefit analysis of regulatory initiatives is generally desirable and ... most of the conventional criticisms of it are unconvincing.") with Amy Sinden, Cass Sunstein's Cost-Benefit Lite: Economics for Liberals, 29 CoLuM. J. ENVTL L. 191, 192 n.7, 201-12 (2004) (providing literature review of those who continue to disagree with the premises of cost-benefit analysis and cataloging critiques of cost-benefit analysis); Sidney A. Shapiro \& Christopher H. Schroeder, Beyond Cost-Benefit Analysis: A Pragmatic Reorientation, 32 HARV. ENVTL L. REV. 433, 453 (2008) ("The inability of [cost-budget analysis] to measure regulatory costs and benefits accurately in many situations is well known. This obviously limits the usefulness of [cost-benefit analysis] in determining the economic efficiency of proposed regulations.").

124. See, e.g., PEARCE \& MILLER III, supra note 91, at 16 (reviewing various studies that have measured the interest rate reduction to conforming borrowers as being between 24 and 43 basis points); Congressional Budget OfFICE, Assessing The Public Costs and Benefits of Fannie Mae and Freddie Mac (May 1996), available at http://www.cbo.gov/doc.cfm?index=13\&type =0 (comparing value of Fannie and Freddie credit-enhancement subsidies to benefits passed through to home buyers and finding that Fannie and Freddie retain nearly one-third of that subsidy); see also Anthony B. Sanders, Government Sponsored Agencies: Do the Benefits Outweigh the Costs?, 25 J. REAL EST. FIN. \& ECON. 121 (Sept. 2002) (comparing cost of implied guarantee with benefit of reduced mortgage interest rates, without deciding whether the one outweighs the other).

125. See PEARCE \& MiLlER III, supra note 91, at 38-44 (containing extensive bibliography of cost/benefit studies of Fannie and Freddie). Freddie Mac has funded or otherwise supported a significant amount of research to support its own position. See, e.g., id. (study prepared for Freddie Mac); Kupiec \& Nickerson, supra note 98, at 123 (study by former Freddie Mac consultant finding that systemic risk might be controlled by lowering capital requirements for housing GSEs); Quercia, et al., supra note 110 (study by authors including at least one Freddie Mac consultant finding that Fannie and Freddie activities increase rate of homeownership, particularly for minorities); Richard Roll, Benefits to Homeowners from Mortgage Portfolios Retained by Fannie Mae and Freddie Mac, 23 J. FIN. 
die know that this debate is fundamentally about their right to exist as GSEs. Their critics, on the other hand, have become increasingly strident in their criticism of the Fannie and Freddie business model as these companies have grown far beyond the expectations of anyone who had studied them in the 1970s and 1980s. ${ }^{126}$

While this body of literature has provided many insights into Fannie and Freddie, it does not provide an overarching theoretical framework that would help determine their value. Such a framework should describe the ecology of Fannie and Freddie as well as the incentives and structural limitations that drive the development of the two companies. It should also provide guidance as to how they should be treated going forward. ${ }^{127}$

\section{Fannie and Freddie Evaluated through the Lens of Regulatory Theory}

Given Fannie and Freddie's monstrous size and market power, there are no comparable public/private hybrid entities. As products of regulation, however, they fit well within existing theories of regulation. This Subpart evaluates their value as agents of public policy through the lens of regulatory theory.

Two oft-stated objectives of government economic policy are to maintain and encourage competition between firms in order to increase "the material welfare of society" 128 as well as to maximize consumer welfare

\footnotetext{
SERVICES RES. 29 (2003) (study by Freddie Mac consultant finding that Fannie and Freddie increase liquidity in secondary mortgage market by purchasing their own RMBS); Frank E. Nothaft et al., Debt Spreads Between GSEs and Other Corporations, 25 J. REAL EST. FIN. \& ECON. 151 (2002) (study by Freddie Mac-affiliated researchers finding that GSE funding advantage in long-term debt is somewhat lower than estimates of other researchers); Robert Van Order, Comment: Some Notes of the Effects of Fannie Mae and Freddie Mac on Mortgage Markets, 23 J. REAL EST. FIN. \& ECON. 365, 373 (2001) (Freddie Mac researcher arguing that " $[\mathrm{m}]$ onopoly power provides incentives to take less risk to keep the franchise.").

126. This is true of the work of Stanton, Wallison and Ely, to name a few. This stridency has also enveloped powerful constituencies within the Democratic and Republican Parties as well as the liberal and conservative media. See, e.g., Editorial, Affordable Housing, N.Y. TIMES, July 3, 2007, at A16 (arguing that only "Hard-line Republicans" oppose compromise on GSE legislation); Editorial, Freddie Guts Frank, WALL ST. J., May 22, 2007, at A14 (arguing that Democratic congressional leaders pretend "to favor reform while letting Fannie and Freddie have their way"); see also JONATHAN G. KOPPELL, THE POLITICS OF QUASI-GOVERNMENT: HYBRID ORGANIZATIONS AND THE DYNAMICS OF BUREAUCRATIC CONTROL 121 (2003) ("Few would have anticipated that Fannie Mae and Freddie Mac would grow into political heavyweights ....").

127. Policy scholars Thomas Stanton and Ronald Moe, taking a different tack, have developed a useful framework for evaluating GSEs. They took part in the "Tools of Government Project," which evaluates an array of government tools pursuant to a consistent set of analytic lenses. The "Tools of Government Project" is a useful exercise for comparing GSEs with other government tools. Stanton and Moe's evaluation of the two companies also lines up with the findings of other independent scholars, but it is somewhat limited (intentionally so) in that it provides a useful way to compare Fannie and Freddie with other "tools of government," but not a comprehensive way of understanding them. Stanton \& Moe, supra note 111.

128. Joseph F. Brodley, The Economic Goals of Antitrust: Efficiency, Consumer Welfare, and Technological Progress, 62 N.Y.U. L. REV. 1020, 1023 (1987).
} 
"through lower prices, better quality and greater choice." 129 Cass Sunstein has rightfully noted that many regulatory regimes therefore reflect "a belief that regulatory enactments might simultaneously promote economic productivity and help the disadvantaged. ${ }^{" 130}$ But Sunstein has also noted that one of the main criticisms of regulation is that it is "[o]nly purportedly in the public interest" and that it "turns out on inspection to be interestgroup transfers designed to protect well-organized private groups . . . at the expense of the rest of the citizenry." 131

Indeed, modern theories of regulation stem from the insight that firms attempt to use regulation as a device "to establish or to enhance monopoly power." ${ }^{132}$ Assessing the role of regulation in a particular market is necessary to understand whether that market is functioning competitively and equitably. ${ }^{133}$ Fannie and Freddie, although born of regulation themselves, claim to act competitively. ${ }^{134}$ Theories of regulation thus provide a useful framework with which to understand the market in which Fannie and Freddie operate, one that allows us to evaluate whether the companies increase "the material welfare of society" and maximize consumer welfare. This Part will analyze Fannie and Freddie as creatures of regulatory privilege within the context of regulatory theory.

The core of Fannie and Freddie's regulatory privilege is the government's guarantee of their obligations, which was initially granted to create a national secondary residential mortgage market. This implied guarantee drives any competition from the conforming mortgage market because the two companies can borrow money so much more cheaply than their competitors. This lower cost of funds means that that they can out-compete

129. Unted States Department of Justice Antitrust Division, Mission of the Antitrust DIVISION, http://www.usdoj.gov/atr/about/mission.htm.

130. Cass Sunstein, AfTER the Rights Revolution: Reconceiving the Regulatory State 3 (1990).

131. Id. at 32; see KeIth N. Hylton, Antitrust LAw: ECONOMIC THEORY AND COMMON LAw EVOLUTION 352 (2003) ("The state is potentially the best friend of the would-be monopolist. The state can erect and enforce entry barriers. The state can enact legislation that hampers the ability of competitors to vie for crucial inputs or the business of big customers."); see also Stacey L. Dogan \& Mark A. Lamley, Antitrust Law and Regulatory Gaming 31 (John. M. Olin Program in Law and Economics, Stanford Law School, Working Paper No. 367, 2008), available at http://ssrn.com/abstract=1287221 (discussing "regulatory gaming" as "behavior that abuses a neutral or pro-competitive regulatory structure," and stressing that monopolistic behavior is a risk in even heavily regulated industries, and the situation is often aggravated by stringent regulation, due to regulatory capture).

132. Crew \& Rowley, supra note 29, at 6-7. Crew and Rowley go on to summarize the major contemporary theories of regulation, including economic, contractual and public choice theories. Id. at 6-15. For the purposes of this Article, "regulation theory" refers to the broadly overlapping portions of these theoretical approaches to regulation that explain the extent to which regulation actually benefits the regulated entity.

133. See Dennis W. Carlton \& Randall C. Picker, Antitrust and Regulation 51 (Nat'l Bureau of Econ. Research, Working Paper Series, Working Paper No. 12902, 2007), available at http://www.nber.org/papers/w12902.pdf (discussing antitrust and regulation as two complimentary aspects of competitive policy).

134. See supra Part II.A. 
fully private financial institutions in the conforming market, thereby keeping the conforming sector to themselves. ${ }^{135}$

The government guarantee is a variant on the longstanding government practice of spurring private investment in various arenas by granting some privilege or monopoly power to a party that will infuse the activity with needed capital or bring focused attention to it. For example, governmentgranted monopolies can take the form of a charter granting a monopoly on trade, such as the one granted by Queen Elizabeth I to the English East India Company in 1600 in order to increase English trade with Asian nations. ${ }^{136}$ They can take the form of a system such as that governing American patents, granting patent-holders the sole right to exploit a patent for a certain period in order to encourage innovation. ${ }^{137}$ Or they can take the form of a regulated natural monopoly, like a utility company, that is regulated not only to protect consumers from monopoly pricing but also to ensure that the company can make a fair return on its investment. ${ }^{138}$

Unlike true monopolists, Fannie and Freddie are limited by the nature of their competitive advantage: in an otherwise efficient market, the maximum amount that they can retain as economic rent is the spread between the interest rates they must pay and those that their competitors must pay. ${ }^{139}$ Notwithstanding this cap on profits, Fannie and Freddie share an important characteristic with government-granted monopolies: a legally created and overwhelming competitive funding advantage in a particular market that derives from their special charters. This advantage translates into higher prices for consumers than would exist if Fannie and Freddie did not retain a portion of their economic rent for shareholders and management.

Regulatory theory identifies six goals that are relevant to a study of Fannie and Freddie, including: (i) maintaining competition, (ii) efficiently allocating society's goods and services, (iii) promoting innovation, (iv) preventing inappropriate wealth transfers, (v) preserving consumer choice, and (vi) preventing an overly-concentrated economy. ${ }^{140}$ The first three

135. See OFHEO, Systemic Risk: FANNIE Mae, Freddie MAC AND the Role OF OFHEO, supra note 98 , at $41-43$.

136. See Philip Lawson, The East India Company: A History 5-6 (1993). As Thomas Stanton has noted, the Boston Tea Party was directed against the tea of the monopolistic East India Company. StANTON, supra note 100, at 106; see generally BENJAMin WOOdS LABAREe, THE Boston TEA PARTY (1981).

137. See U.S. ConsT. art. $1, \S 8$.

138. See Peter Z. Grossman \& Daniel H. Cole, Introduction, in The END of A NATURAL Monopoly: Deregulation and Competition In the Electric Power Industry 1-10 (Peter Z. Grossman \& Daniel H. Cole eds., 2003).

139. See Stephen G. BREYer, RegUlation AND ItS REForm 18 (1982).

140. See Seiler, supra note 98, at 118 ("Economic regulation is intended to address problems of monopoly, extreme concentration in an industry, or the social or political power of large corporations."); $c f$. LaWrence A. Sullivan \& Warren S. Grimes, The LaW of antitrust: AN INTEGRATED HANDBOOK 10-19 (2d ed. 2006) (reviewing these goals in antitrust regulation context). 
goals relate to economic efficiency concerns. ${ }^{141}$ The second three goals address additional public policy objectives. As shall be seen below, Fannie and Freddie do little to effectuate these goals. Indeed, in some cases they act contrary to them.

(i) Maintaining Competition. Maintaining competition is one of the most important goals of economic regulation. ${ }^{142}$ But applying this goal to Fannie and Freddie's activities is a bit difficult, as there was no real national mortgage market when they were created. Indeed, they were formed in order to create something new-the fungible mortgage security. So, to begin with, there was barely any competition with which Fannie and Freddie could interfere. And now, because of their funding advantage, they have no competitors in the prime sector of the modern residential mortgage market. Should there be more competition in the conforming mortgage market? And, should Fannie and Freddie be allowed to expand the markets in which they compete while maintaining their funding advantage?

As to the first question, it is not controversial to answer that competition is considered healthy in almost all markets, except for those that are better suited to natural monopolies like the utilities market. While Fannie and Freddie maintain that they compete with each other, independent commentators discussed above describe their behavior more as that of duopolists than competitors. ${ }^{143}$ As to the second question, it again is not con-

141. Areeda and Hovenkamp note that "economic concerns have generally dominated antitrust policy and trumped competing 'populist' concerns ...." PHILLIP E. AREEDA \& HERBERT HOVENKAMP, I ANTITRUST LAW 97 (3d ed. 2010). Areeda and Hovenkamp, as well as Judge Richard Posner, are examples of those who fall into the economic efficiency camp.

142. See generally HYLTON, supra note 131, at 1-19. "Optimal competition," as an economist would understand it, exists "when the firms in a market price their output at marginal costs and costs are minimized by internal efficiency, research and development, attainment of economies of scale or scope." AREEDA \& HovENKAMP, supra note 141, at 3.

143. Robert Seiler and others argue that Fannie and Freddie have a number of characteristics of duopolists. Seiler, supra note 98, at 125; see Benjamin E. Hermalin \& Dwight M. Jaffee, The Privatization of Fannie Mae and Freddie Mac: Implications for Mortgage Industry Structure, in U.S. DEP'T of Housing \& URban Dev., Studies on PRIVAtizing Fannie MaE ANd Freddie MaC 225 (1996) (arguing that there is empirical support for finding that Fannie and Freddie have opportunities to collude, based on historically high profits); John L. Goodman \& S. Wayne Passmore, Market Power and The Pricing of Mortgage Securitization 2 (Fed. Reserve Bd. Fin. \& Econ. Discussion Series, Number 187,1992 ) (noting that conforming market is a classic duopoly); see also Lawrence White \& W. Scott Frame, Fussing and Fuming over Fannie and Freddie: How Much Smoke, How Much Fire? 26 (NYU Stern, Working Paper No. 04-27; Fed. Reserve Bank of Atlanta, Working Paper No. 200426, 2004), available at http:// ssrn.com/ abstract $=604525$ ("The empirical evidence suggests that Fannie Mae and Freddie Mac do retain some portion of their federal benefits and hence are not acting in a perfectly competitive manner."). Fannie Mae, unsurprisingly, disagrees with this assessment. See Seiler, supra note 98, at 125; Susan E. Woodward, Rechartering Freddie Mac and Fannie Mae: The Policy Issues 27-31 (Sand Hill Econometrics, Working Paper, 2005) (on file with author) (former Freddie Mac consultant, disputing the notion that Fannie and Freddie act as duopolists because of the murkiness in market for Fannie and Freddie's guarantee fees); Robert Van Order, A Microeconomic Analysis of Fannie Mae and Freddie Mac, 23 REG. (2000), available at http:// ssrn.com/ abstract $=235869$ (former chief economist at Freddie Mac, arguing that GSEs' activities could not both distort mortgage prices to be lower while constraining competition and driving mortgage prices to be 
troversial to state that introducing subsidized firms like Fannie and Freddie into a generally efficient non-subsidized mortgage market like the jumbo market would distort pricing in that market.

And, Fannie and Freddie are entering that jumbo market; the rapidly increasing size of the conforming loan limit, a product of furious lobbying by the two firms, allows Fannie and Freddie to claim more of the overall mortgage market for themselves as opposed to their jumbo-originating competitors. ${ }^{144}$ As Fannie and Freddie both operate without competition in the conforming market and expand their markets through political action, they seem to operate contrary to the goal of maintaining competition.

Moreover, if one believes that Fannie and Freddie were primarily created to develop the national mortgage market, then it follows that their government-granted privilege should be revoked after they have completed that task. That is, Fannie and Freddie's regulatory privilege should be treated more like the privilege granted to patents-which only allows for a temporary monopoly for the express purpose of encouraging innovationrather than a natural monopoly, like that of utility companies, which are typically regulated in perpetuity because they have no potential competition.

(ii) Efficiently Allocating Society's Goods and Services. In a productively efficient system, each unit of a product is produced at the lowest possible cost. ${ }^{145}$ If a producer in a competitive market fails to produce its product at the lowest possible cost, it would likely fail. This result would not typically apply to a monopolist because it does not face competition in its market. ${ }^{146}$ Monopolists thus typically "lack sufficient incentive to hold production costs at low levels." ${ }^{147}$

\footnotetext{
higher).

144. See, e.g., supra note 81 and accompanying text. Before the credit crisis, they were also becoming formidable competitors in the subprime conforming market, which they had avoided until recently in favor of the prime conforming market. See Reiss, supra note 113, at 1033. The regulation of Fannie and Freddie may perversely result in "cream-skimming," a problem that is generally considered to be a rationale for a regulated monopoly, not a result of a regulated monopoly. "Creamskimming" refers to the practice of only choosing to enter into the lucrative parts of a market. See Alfred E. Kahn, The ECONOMics of Regulation: PRinCiples and Institutions 7 (1988). In order to prevent the other parts of such a market from being underserved, a regulatory scheme might bar competitors intent on cream-skimming from the entire market. The limitations on which loans Fannie and Freddie can buy and guarantee have effectively given them a monopoly over certain creamy parts of the market (the reliably profitable conforming sector) and may bar them from entering the skimmed portions of the market (the volatile subprime sector).

145. See Rudolph J. R. Peritz, Competition Policy in America: History, Rhetoric, Law 238-42 (2000).

146. This assumes that there are no easily acceptable substitute products for the monopolist producers. See RICHARD A. POSNER, ECONOMIC ANALYSIS OF LAW 254-55 (3d ed. 1986).

147. BREYER, supra note 139, at 16; see Froomkin, supra note 93, at 618. See also U.S. DEP'T OF the TREASURY, REPORT OF tHE SEC. OF THE TREASURY ON GOV'T-SPONSORED ENTERPRISES 8 (1991) (noting that due to GSEs' special privileges, they are "effectively insulated from private market discipline.").
} 
The competitive advantage provided by Fannie and Freddie's regulatory privilege is limited, as discussed above, by the fact that they would face competition if the price (interest rate and fees) in the conforming market was equal to or higher than the price in the private-label market. But so long as they keep the price lower than the price in the private-label market, they are able to extract some economic rent. ${ }^{148}$ Thus, they are not efficiently allocating society's goods and services.

Regulatory privilege imposes certain additional social costs. Its beneficiaries incur costs to retain and expand it, often through campaign contributions, lobbying, and bribery. ${ }^{149}$ Such firms are also more likely to dissipate their rents through expenditures such as advertising in order to protect their privileged status. ${ }^{150}$ Fannie and Freddie are thus best understood as rent-seekers who expend resources to obtain favorable regulation in order to obtain rents.

(iii) Promoting Innovation. Recipients of regulatory privilege may have less impetus to innovate because of their competitive advantage. ${ }^{151}$ Fannie and Freddie claim, however, that they continue to innovate as the secondary market matures. ${ }^{152}$ Indeed, they have executed a number of in-

148. See, e.g., Seiler, supra note 98, at 132 (citing three studies that support a finding that Fannie and Freddie "are pricing their mortgage guarantee services above competitive levels"). There is also some evidence that Fannie and Freddie engage in price discrimination by setting their mortgage guarantee fees higher for smaller lenders. Id. at 132-33.

149. See, e.g., Keith Cowling \& Dennis C. Mueller, The Social Costs of Monopoly Power, in TOWARD A THEORY OF THE RENT-SEEKING SOCIETY 125, 134 (J.M. Buchanan et al. eds., 1980). Fannie and Freddie have spent over $\$ 170,000,000$ on lobbying since 1998 and gave $\$ 1,500,000$ to Congressional campaigns in the 2008 election cycle. Elizabeth Williamson, Troubles May Diminish Fannie and Freddie's Lobbying Clout, WALL ST. J., July 18, 2008, at A10. Fannie and Freddie are two of the top twenty lobbyists from 1998 to 2008; if their spending was combined, they would rank third. Center for Responsive Politics, Lobbying: Top Spenders, http:// web.archive.org/ web/ 20080512232835 / www.opensecrets.org/ lobby/ top.php?indexType=s (last visited Sept. 28, 2010); see STANTON, supra note 100 , at 75 (demonstrating that Fannie and Freddie had combined 1998 lobbying expenditures that exceeded those of other major housing market players). The costs incurred by Fannie and Freddie's competitors to reduce their regulatory privileges or to co-opt such privileges for themselves is an additional cost to society imposed by the Fannie/Freddie duopoly. See Gordon Tullock, The Welfare Costs of Tariffs, Monopolies, and Theft, 5 W. ECON. J.L 224, 232 (1967) ("[T]he total costs of monopoly should be measured in terms of the efforts to get a monopoly by the unsuccessful as well as the successful.").

150. Cowling \& Mueller, supra note 149, at 141. See also NEIL K. KOMESAR, IMPERFECT Alternatives: Choosing Institutions in LAW, ECONOMICS, AND PUBlic PoliCy 115-19 (1994) (noting that rent seeking skews distribution of resources toward lobbying efforts); JAMES $\mathbf{M}$. Buchanan, From Private Preferences to Public Philosophy: The Development of Public Choice, in POLITICS As PUBLIC CHOICE 39, 50 (1978) ("when politics creates profit opportunities or rents ... we can expect resource waste in investments to secure the favoured plums.").

151. See ROGER SHERMAn, THE REGUlation OF MONOPOLY 64 (1989) (arguing that governmentcreated monopolies face only a "slight threat" of competition and as a result they may have "no great urge to innovate"). But see RiCHARD A. POSNER, ANTITRUST LAw 20 (2d ed. 2001) ("[1] is an empirical question whether monopoly retards or advances innovation.").

152. See, e.g., Proposals for Improving the Regulation of the Housing Government Sponsored Enterprises: Hearing Before the S. Comm. on Banking, Housing and Urban Affairs 108th Cong. 18 (2004) (statement of Franklin D. Raines, Chief Executive Officer, Fannie Mae), available at http://banking.senate.gov/public/index.cfm?FuseAction=Files.View\&FileStore_id =8e7a4038-9ad0- 
novations that allow them to profit from aspects of the mortgage market that had traditionally fallen outside of the scope of their activities. These include, for instance, the development of automated underwriting systems and underwriting guidance systems for third parties. ${ }^{153}$ It is no coincidence that these innovations allow the two companies to enter new markets, thereby pushing against the limitations on their expansion into new markets contained in their charters. ${ }^{154}$ The Mortgage Bankers Association argues that in the area of underwriting technology, Fannie and Freddie have actually squelched the innovations of others, ${ }^{155}$ much as Microsoft has squelched its competitors by tying new products to its operating software. ${ }^{156}$

Private-label competitors have innovated at a far greater rate than Fannie and Freddie, introducing a dizzying array of products for consumers to choose from and securities for investors to choose from, although much of that innovation now seems foolish, greedy, and wrongheaded. ${ }^{157}$ At a minimum, there is no evidence that Fannie and Freddie innovate

\footnotetext{
46bf-aa39-8c2f83f8a6c8 ("We work every day to innovate and develop creative ways to bring homeownership opportunities to all corners of the nation.").

153. See StANTON, supra note 100 , at 8.

154. See Seiler, supra note 98, at 130 ("The regulated firm may be able to use profits from its regulated markets to fund a policy of predatory pricing in new, unregulated markets. . . . If a regulated product is an input in the production of an unregulated product, a regulated monopolist will also try to control the supply of competitors through its control of the regulated product."). Fannie and Freddie's incursions into the loan underwriting technology market may, for instance, blur the line between the secondary mortgage market, where they are allowed to operated, and the primary mortgage market, where they are barred from operating. See generally MORTGAGE BANKERS ASSOCIATION, supra note 65, at 4. See also Housing Enterprises: The Roles of Fannie Mae and Freddie Mac in the U.S. Housing Finance System Before the H. Budget Comm. Task Force on Housing and Infrastructure, 106th Cong. 7 (2000) (statement of Thomas J. McCool, Director, Financial Institutions and Markets Issues, U.S. General Accounting Office (GAO)), available at http:// www.gao.gov/ archive/ 2000/ gg00182t.pdf (noting that the GSE's forays into automated underwriting may signal move to expand into new areas of the mortgage industry).

155. See MORTGAGE BANKERS ASSOCIATION, supra note 65, at 4 ("[T] he GSEs have established a duopoly in loan underwriting technology."); see also Jie Gan \& Timothy J. Riddiough, Monopoly and Information Advantage in the Residential Mortgage Market, 21 REV. FIN. STUD. 2677, 2678 (2008) ("GSEs effectively lend directly to consumers as an informationally advantaged monopolist."). But even longstanding Fannie/Freddie critic Stanton acknowledges that the two companies "have been among leaders in their segments of the market in adopting new technology-based servicing, loan management, and loan underwriting systems." Stanton \& Moe, supra note 111 , at 110.

156. See Peter J. Wallison, Applying the Microsoft Decision to Fannie Mae and Freddie Mac, in COMPETING WITH THE GOVERNMENT: ANTICOMPETITIVE BEHAVIOR AND PUBLIC ENTERPRISES 59 (R. Richard Geddes ed., 2004) (applying reasoning of Microsoft decision to Fannie and Freddie's role in the automated underwriting market); Dennis W. Carlton \& Michael Waldman, The Strategic Use of Tying To Preserve and Create Market Power in Evolving Industries, 33 RAND J. ECON. 194 (Summer 2002).

157. See, e.g., Edmund L. Andrews, Loose Reins on Galloping Loans; Efforts To Regulate Risky Mortgage Innovations Are So Far Ignored, N.Y. TIMES, July 15, 2005, at C1 (describing complex mortgage-backed securities offerings); James R. Hagerty, Mortgage-Bond Pioneer Dislikes What He Sees, WALL ST. J., Feb. 24, 2007, at B1 (describing risky residential mortgage products). As these two representative news articles indicate, this innovation has its downsides, for both consumers and investors, if they do not properly judge the risks posed by such innovations.
} 
more than they would if they faced a marketplace filled with many competitors. ${ }^{158}$ That being said, as the subprime crisis unfolds, the once vaunted innovation of private-label lenders has taken on a decidedly morbid pall. Kathleen Engel and Patricia McCoy argue quite convincingly how the business model of these private-label lenders led directly to much of the abusive lending of the last ten years. ${ }^{159}$ One might have argued that this goal of regulatory theory should weigh in favor of Fannie and Freddie if they themselves did not invest so heavily in subprime and Alt-A mortgages originated by the very same private-label lenders that engaged in such dangerous innovations.

(iv) Preventing Inappropriate Wealth Transfers. Monopolists are willing to forgo sales for increased profits. ${ }^{160}$ Similarly, Fannie and Freddie forgo offering the lowest possible price for mortgages; they do this by retaining a portion of their subsidy, instead of passing it on to borrowers as they would in a perfectly competitive market. ${ }^{161}$ This is reflected in the outsized profits that Fannie and Freddie have historically enjoyed as compared to other financial institutions. ${ }^{162}$ It may also be reflected in the generous pay packages that management awards itself before turning over the remainder of the economic rent to shareholders. ${ }^{163}$

Furthermore, monopoly pricing dissuades some buyers who would have purchased a good at a competitive price from doing so at the mono-

158. See SHERMAN, supra note 151, at 63 (noting that "hordes of potential competitors" can spur management effort more than anything else).

159. See Kathleen C. Engel \& Patricia A. McCoy, Turning a Blind Eye: Wall Street Finance of Predatory Lending, 75 FORDHAM L. REV. 2039 (2007).

160. See BREYER, supra note 139, at 15-16; see SHERMAN, supra note 151, at 65 ("[T] he monopoly tendency is to set price above marginal cost.").

161. See supra note 124 and accompanying text. Profits reported by a monopolist understate the true economic profit to the extent that the firm competes for monopoly power by investing for the purpose of maintaining the monopoly. See Cowling \& Mueller, supra note 149, at 150 . For a defense of the GSEs" profit yield against "controversial studies" that link company profits with an implicit subsidy, see Michael Fratantoni \& Peter Niculescu, Subsidies in a Context of Efficient Markets: A New Framework for Evaluating the Role of Fannie Mae (Working Paper Series, 2005), available at http://ssrn.com/abstract $=841345$. The paper argues that the efficiency of financial markets prevents extraordinary profits, as MBS yields will decline by the same amount as debt yields, and any profit is the result of efficiencies of size and expertise in risk management Its co-author, Peter Niculescu, was an executive vice-president at Fannie Mae at the time of its writing.

162. See White \& Frame, supra note 143 , at 26 (The authors noted the extraordinary profitability of Fannie and Freddie for the years 1998-2002 in which "Fannie Mae earned an average return on equity of 25.4 percent while Freddie Mac earned an average of 24.2 percent. By contrast, the industry return on equity for all FDIC-insured commercial banks for the same five years was around 14 percent."). While they have generally enjoyed high profits, Fannie and Freddie's large losses in 2008, of course, led to their entering conservatorship. See supra Part I.D.

163. See Froomkin, supra note 93, at 580 ("The greatest microeconomic concerns [relating to federal government corporations] are self-dealing, and management or shareholder enjoyment of a publicly created rent, free of charge."). Fannie Mae management, in particular, has awarded itself outsized pay packages in recent years. See, e.g., Editorial, Ill-Gotten Raines, WALL ST. J., Dec. 20, 2006 , at A18 (praising OFHEO suit seeking $\$ 115$ million in restitution of ill-gotten pay from former members of Fannie management). This is not to say that other financial firms do not provide astronomical compensation to their executives, but just to say that Fannie operates in that same league. 
poly price, which is allocatively inefficient. Fannie and Freddie's retention of a portion of their subsidy likewise keeps some potential borrowers from borrowing. ${ }^{164}$

(v) Preserving Consumer Choice. Government regulates businesses that operate in markets that are not fully competitive, in part, to achieve fairness for consumers. ${ }^{165}$ Because of their competitive advantage in the conforming loan market, consumers effectively only have the choice of Fannie or Freddie. As noted above, Fannie and Freddie argue convincingly that they have helped to standardize the prime, conforming mortgage to the benefit of consumers. ${ }^{166}$

There is no question that private label firms would enter the conforming market if they were able to borrow funds at rates comparable to those available to Fannie and Freddie. ${ }^{167}$ The pros and cons of those privatelabel firms have been well documented in the jumbo and subprime markets: they expand consumer choice but often at the expense of the consumer protection inherent in a standardized market place. ${ }^{168}$ More competitors would, of course, mean more consumer choice of lenders. It would also likely mean more choice of mortgage products. But in the context of mortgage lending, more consumer choice is a two-edged sword, as the recent implosion of the subprime market attests. ${ }^{169}$

Fannie and Freddie also argue that they implement the government's policy of increasing homeownership; indeed, Fannie's slogan is "Our Business is the American Dream." 170 They claim that they have thereby helped the nation achieve a great increase in the rate of homeownership. This claim is undercut in a variety of ways. First, the credit crunch has made some question whether homeownership is a good in and of itself for all households. ${ }^{171}$ Second, some scholars argue that America overinvests in

164. See PERITZ, supra note 145 , at 238-42. Allocative efficiency is achieved when "goods and services to those who value them the most." Id. at 239.

165. See BREYER, supra note 139 , at 20.

166. See supra text accompanying notes 112-114; see also Fannie Mae, Introducing Fannie Mae, supra note 112, at 4; Freddie Mac, Just The Facts: How We Make Home Possible, supra note 112, at 5.

167. See Reiss, supra note 113, at 1011-12.

168. See generally Engel \& McCoy, supra note 159.

169. Ruth Simon \& James R. Hagerty, Mortgage Defaults Start To Spread: New Data Show That Nontraditional Loans Are Beginning To Haunt Borrowers with Midlevel Credit; Prime Still Fine, WALL ST. J., Mar. 1, 2007, at D1.

170. Fannie Mae, Understanding America's Homeownership Gaps: 2003 Fannie Mae National Housing Survey (2003), available at http:// www.fanniemae.com/ global/ pdf/ media/ survey/ survey2003.pdf. Freddie Mac's slogan is "We make home possible." Freddie Mac Homepage, http:// www.freddiemac.com/ (last visited Oct. 1, 2010). Right before the credit crisis (and intimately linked to it), homeownership in America approached $70 \%$, the highest rate in history. See HARVARD JOINT CENTER FOR HOUSING STUDIES, STATE OF THE NATION'S HOUSING 20065 (2006), available at http:// www.jchs.harvard.edu/ publications/ markets/son2006/son2006_bw.pdf.

171. See, e.g., Paul Krugman, Home Not-So-Sweet Home, N.Y. TIMES, June 23, 2008, at A21; James Surowiecki, Home Economics, THE NEW YORKER, Mar. 10, 2008, at 48; Nick Timiraos, Homeownership Push Is Rethought-Both Candidates Weigh the Best Path to American Dream, WALL 
housing and that Fannie and Freddie are part of that problem. ${ }^{172}$ Third, it is unclear whether they actually help to fund affordable housing for lowand moderate-income homeowners, who should presumably be the main beneficiaries of such a government initiative. ${ }^{173}$ Fourth, the amount that the typical homeowner saves because of Fannie and Freddie is relatively modest. ${ }^{174}$

(vi) Preventing an Overly Concentrated Economy. Regulation may be employed to reduce over concentrations of market power. ${ }^{175}$ Fannie and Freddie argue, however, that their vast size provides stability to the mortgage market; independent scholars disagree. ${ }^{176}$ Recent events further disfavor the Fannie/Freddie perspective. Both Fannie and Freddie present an over concentration of risk that is perhaps unsurpassed by any other private firm operating anywhere in the world. Because the two companies have the identical, undiversified business model, that risk is only magnified. Thus, any substantial operational risk or mistaken hedging strategy at ei-

ST. J., Sept.12, 2008, at A4.

172. See, e.g., Lori L. Taylor, Does The United States Still Overinvest in Housing? 1998 ECON. \& Fin. POL'Y R 10; Lawrence J. White, On Truly Privatizing Fannie Mae and Freddie Mac: Why It's Important and How To Do It, Housing Fin. INT'L, Dec. 2005, at 10; see also Pamela J. Jackson, Fundamental Tax Reform: Options for the Mortgage Interest Deduction 6 (August 8, 2005) (CRS Report for Congress).

173. See supra note 110. A Federal Reserve working paper found that the subsidy to homeowners that results from the implied guarantee actually "mostly benefits high income and mostly high wealth households." Karsten Jeske \& Dirk Krueger, Housing and the Macroeconomy: The Role of Implicit Guarantees for Government-Sponsored Enterprises 17 (Federal Reserve Bank of Atlanta Working Paper 2005-15, 2005), available at http://www.frbatlanta.org/filelegacydocs/wp0515.pdf; see also Dawn Kopecki, Study Faults Federal Home-Lending Subsidies as Aiding Wealthy, WALl ST. J., Aug. 17, 2005, at A4 (reporting Freddie Mac's criticisms of Kekse/Krueger paper).

174. See note 92 and accompanying text.

175. See BREYER, supra note 139, at 20.

176. Compare Benton E. Gup, Are Fannie Mae and Freddie Mac Too Big To Fail?, in Too BIG To FAIL: Policies AND PRACTICES IN GovernMENT BaIlouts 287, 315 n.28 (Benton E. Gup ed. 2004) ("In their responses to an OFHEO inquiry for public comments with respect to systemic risk in 2001, Fannie Mae asserts 'far from being a source of systemic risk, Fannie Mae operates to stabilize the financial markets in which it operates . . . regardless of which definition [of systemic risk] is applied, Fannie Mae does not pose systemic risk.' Freddie Mac states that it 'is the least likely of large financial institutions to cause significant financial disruptions . . . . Our credit risk, interest-rate risk, capital management and disclosure practices make Freddie Mac strong and well managed."') and White \& Frame, supra note 143, at $22 \mathrm{n} .11$ (reviewing literature that suggests "that because of their implicit government guarantees, the companies might also act as a source of strength to financial markets in the face of external shocks"), with Dwight M. Jaffee, Controlling the Interest Rate Risk of Fannie Mae and Freddie Mac 1 (Networks Fin. Inst., Policy Brief No. 2006-PB-04, Apr. 2006), available at http://ssrn.com/abstract $=923568$ ("It is now widely recognized that the interest rate risks embedded in the Fannie Mae and Freddie Mac (F\&F) retained mortgage portfolios create a serious threat to the US financial system."). Notwithstanding this dispute, nearly all commentators agree that GSEs are generally successful at making credit more available and more liquid in the particular markets in which they operate. See, e.g., Michael J. Lea, Privatizing a Government Sponsored Enterprise: Lessons from the Sallie Mae Experience 15 (Networks Fin. Inst., Policy Brief No. 2006-PB-09, Apr. 2006), available at http://ssrn.com/abstract=923461 ("From the perspective of credit availability, the GSE concept has been a major success."). 
ther of those firms poses a systemic risk to the international economy-a risk that has already become a reality. ${ }^{177}$

Fannie and Freddie do not do well when these six regulatory goals are taken together. As to the three economic efficiency goals, the conforming market is not as competitive or efficient as it would be if there were more competitors. ${ }^{178}$ There is also no evidence that the market is more innovative than it would be if there were more competitors. Thus, merely on economic efficiency grounds, Fannie and Freddie's regulatory privilege does not serve the public interest. Nor do Fannie and Freddie do particularly well with the other public policy goals. The two companies engage in rent-seeking, limit consumer choice, and keep other firms from competing with them.

The two areas where Fannie and Freddie seem to offer some clear and significant benefits are (i) providing short term liquidity and stability to the mortgage market during an acute crisis and (ii) in the area of consumer protection, at least in the prime, conforming sector. This second point is underscored by the events leading up to the credit crisis, which have demonstrated that too much consumer choice in the mortgage arena can lead to horrible results. If the benefits offered by Fannie and Freddie could be undertaken through alternate means, one might conclude that Fannie and Freddie are not particularly beneficial agents of public policy.

In sum, regulatory theory helps to untangle Fannie and Freddie's intended market function from their intended public mission and to explain how the two purposes do not work well individually or taken together. Because Fannie and Freddie are creatures of federal regulatory privilege, and not independent firms that are operating in a relatively unregulated market, the federal government has broad latitude in setting new goals for these two firms and modifying the regulatory privileges awarded to them. ${ }^{179}$

177. See Reiss, supra note 2, at 1031-32 (discussing risks of Fannie/Freddie business model).

178. Notwithstanding the fact that Fannie and Freddie do not appear to be particularly efficient, there is often a bias in favor of privatizing government functions. See Froomkin, supra note 93, at 558 ("[Federal government corporations] conjure up an image of business efficiency as opposed to the traditional bureaucratic cabinet department. Proponents of small government may welcome the introduction of an element of private control into most realms of public administration as a means of preparing for the privatization of federal functions. Democratic socialists may view wholly or even partly owned government corporations as a means of capturing the rents and profits from public activities or natural monopolies for the benefit of the public fisc.").

179. Farmer Mac, a GSE and a publicly traded corporation like Fannie and Freddie, is able to exploit its regulatory privilege in similar ways to the two companies, although it operates in a smaller market. See Farmer Mac website, http://www.farmermac.com/company/profile/profile.aspx (last visited Sept. 28, 2010); Press Release, Farmer Mac, Farmer Mac Reports 2006 Third Quarter Results and Completes Financial Restatement - Business Volume for Quarter a Record \$1.3 Billion (Nov. 9, 


\section{FANNIE AND FREDDIE'S GSE STATUS SHOULD BE TERMINATED}

Identifying the weaknesses of Fannie and Freddie as agents of public policy is very different from identifying what should be done with them. The two companies have two of the most powerful lobbying machines in Washington. Moreover, the nature of Fannie and Freddie's privileges makes it unlikely that they will be revisited by Congress with any regularity. Because Fannie and Freddie are poor agents of public policy and are political powerhouses with unmatched influence, the two companies should be fully privatized.

\section{A. Fannie and Freddie Are Political Powerhouses}

Jonathan Koppell has thoroughly documented how Fannie and Freddie have been able to exercise unparalleled influence in Washington. ${ }^{180}$ Mirroring the hybrid analysis in this Article, he concludes that it is the combining of elements of public instrumentalities and private companies that is what gives them the "best of both worlds"-in terms of the political influence the two companies can marshal. ${ }^{181}$ Thus, any policy proposals relating to the two companies must be evaluated in the context of the political environment in which they operate.

Given that Fannie and Freddie have outsized influence in Washington, one must be cautious in recommending half-measures in reaction to their limitations as agents of public policy. Unfortunately, most of the reforms floated in the last few years would seem to fall within this category. They include

(1) limiting the size of their mortgage portfolios;

(2) limiting their debt issuance;

(3) stripping [the two companies] of some of their unique privileges to signal to the market that the implied guarantee has been weakened;

(4) freezing the conforming loan value to limit the size of mortgages they can buy, thereby limiting their overall size;

(5) requiring them to obtain ratings from rating agencies for their debt issuances that discount the implied guarantee; in the Financial Crisis Before the H. Comm. on Oversight and Gov't Reform, 110th Cong. 1 n.1 (2008) (providing litany of GSE reform legislation blocked since 2000).

181. See KOPPELL, supra note 126, at 102-03. 
(6) imposing user fees; and

(7) strengthening their subordinated debt programs. ${ }^{182}$

If any of these half-measures were adopted, however, Fannie and Freddie's lobbying juggernaut would be sure to undercut them as soon as Congress's focus moved on to another pressing issue. ${ }^{183}$

\section{B. The Government Guarantee Is a Reckless Budgeting Device}

Michael Froomkin, among others, has identified the encouragement of federal budget shenanigans as a hard to quantify "cost" of the Fannie and Freddie hybrid business model. This is because the federal government's contingent liability for its guarantee of Fannie and Freddie's obligations is off-budget, allowing Congress to avoid having that liability trigger debt ceiling limits. ${ }^{184}$ If off-budget accounting is a bad sign when found in corporations such as Enron, it is at least as bad for the federal government. For, while the federal government was ultimately able to investigate Enron, who will watch the watchers? Indeed, if the federal government had to quantify and account for this contingent liability in its budget, it would most certainly reduce Congress's ability to increase net spending. ${ }^{185}$

Fannie and Freddie, thus, pose four serious budgetary problems. First, the cost of the government's guarantee is hidden because it is off-

182. See Reiss, supra note 2, at 1076-77. See also Hans-Joachim Beyer et al., Economic and Legal Considerations of Optimal Privatization: Case Studies of Mortgage Firms (DePfa Group and Fannie Mae) (Int'l Monetary Fund, Working Paper No. 99/69, 1999), available at http:// ssrn.com/ abstract $=880596$ (contrasting the successful public-to-private transformation of the German mortgage bank DePfa with the equally unsuccessful struggles to reform Fannie Mae).

183. See KOPPELL, supra note 126, at 164 (arguing that use of hybrid entities like Fannie and Freddie lead to government's loss of control over public policy). Even the Treasury Department has noted that the "problem of avoiding capture appears to be particularly acute in the case of regulation of GSEs." STANTON, supra note 100, at 44 (quoting 1991 Treasury study). A further challenge the GSEs lobbying arm presents is requiring the untangling of market complexities, and the danger of politicians underestimating how seemingly minor policy changes, often clothed in the guise of serving the GSEs' public mission, can have drastic ramifications in the financial and mortgage markets. See Thomas H. Stanton, The Administrative Conference of the United States: A Resource to Help Policymakers Deal with the Legal Framework of Third Party Government, Before the Section of Admin. Law, American Ass'n of Law Schools Annual Meeting 6-7 (Jan. 3, 2002), available at http:// www.aals.org/ am2002/ stanton.pdf.

184. See Froomkin, supra note 93, at 617-18. The federal budget does, in contrast, include corporations owned in whole or in part by the government. See SCHICK \& LOSTRACCO, supra note 121, at 42.

185. The Congressional Budget Act of 1974, 2 U.S.C. $\S 601-88$, had "the effect of enhancing the value of off-budget status. Off-budget agencies are not included in the aggregate or functional amounts set forth in congressional budget resolutions." Harold Seidman, Public Enterprises in the United States, in 1 AnNals Pub. \& Co-Operative ECON. 8 (1983). The creation of two special-purpose GSEs to provide financing to resolve the savings and loan debacle shows the extent that policymakers have used GSEs to avoid accountability under the federal budget. See generally Thomas H. Stanton, Budgetary Consequences of Using a Government Sponsored Enterprise To Provide Financial Assistance to the Federal Savings and Loan Insurance Corporation, 9 PUB. BudGETING \& Fin. 76 (Autumn 1989). 
budget. ${ }^{186}$ Second, the cost of the guarantee is particularly difficult to quantify. ${ }^{187}$ Third, the cost of the guarantee is not capped by the federal government, given that the federal government has not imposed any meaningful limits on Fannie and Freddie's growth. ${ }^{188}$ Finally, Fannie and Freddie's charters and the costs they might pose to the federal government are infrequently revisited by Congress. Indeed, Congress only takes a serious look at them every ten years or so. ${ }^{189}$

Cheryl Block, in her work on the federal tax budget, proposes a set of principles that should guide the budget legislative process. These principles are built on those relied upon by the General Accounting Office and are (1) budget formation as a democratic exercise, (2) enforceability, (3) accountability, (4) transparency, and (5) openness and durability. ${ }^{190}$ These five principles help to clarify the manner in which the contingent liability of the government's guarantee should be treated in the federal budget process.

The government's guarantee of Fannie and Freddie's obligations, when viewed as an item in the legislative budgetary process, fails to abide by any of these principles. Because the government guarantee of Fannie and Freddie's obligations was effectively created decades ago, it is generally not part of the annual debate surrounding the budget. Because the size of the guarantee is uncapped and contingent, it fails the enforceability and accountability principles: it operates outside of the budget, its cost is hard to estimate, and the trigger for the federal government's obligation to make good on it is in itself an unexpected event. Similarly, the guarantee, because of its contingent nature, is quite confusing to those outside of the budget process. Finally, it fails to meet the openness and durability principles because it is not typically part of the annual budget deliberations.

In sum, the budgetary implications of the government's guarantee provide an additional public policy argument against Fannie and Freddie, one

186. See Cheryl D. Block, Congress and Accounting Scandals: Is the Pot Calling the Kettle Black?, 82 NEB. L. REV. 365, 435-42 (2003) (comparing off-budget nature of GSEs to private sector use of special-purposes enterprises used by corporations like Enron to keep certain activities off of their financial statements).

187. See Reiss, supra note 2, at 1049 n. 132.

188. See id.

189. See id. at 1033-1036; supra Part I.C.

190. See Cheryl D. Block, Pathologies at the Intersection of the Budget and Tax Legislative Processes, 43 B.C. L. REv. 863, 900-04 (2001). While the meanings of some of these principles are clear, a few are not. "Enforceability" refers to mechanisms to enforce budget decisions once they are made. See id. at 901. The government should be "accountable" in two ways for the budget: (a) for the cost of budget items and (b) for the cost of unexpected events. See id. Finally, the phrase "openness and durability" reflects the concern that the budget process be open such that the public can understand and participate in it, and that the process by which the budget is set is reasonably durable so that the public can better understand how it unfolds. Id. at 904. Block has added this last goal to those set forth by the GAO in U.S. General Accounting Office, Budget Process: Evolution AND CHALlENGES, GAO/T-AIMD-96-129, at 12 (1996). 
that, even on its own, weighs heavily against them as agents of public policy.

\section{Fannie and Freddie Should Be Privatized}

There are four broad positions regarding the appropriate role of Fannie and Freddie in the housing finance market. First, Fannie and Freddie are generally doing the job that they were designed to do, although their powers and that of their regulators should be tweaked. Second, Fannie and Freddie are generally doing their job, but they are retaining too much of the value of the government guarantee for the benefit of shareholders and management at the expense of their affordable housing goals. Third, Fannie and Freddie should be nationalized because the federal government has taken on most of the risk associated with them already. And finally, Fannie and Freddie pose a systemic risk to the financial system, unfairly benefit from their regulatory privilege, and do not create net benefits for the American people.

This Article has taken the fourth position. In particular, it argues that the government guarantee should be terminated and the two companies should be privatized. Until they entered conservatorship, this position has been considered a political nonstarter, particularly because Fannie and Freddie have many allies in the Republican and Democratic parties. ${ }^{191}$ Due to recent events, it is now one of the options on the table for a postconservatorship Fannie and Freddie.

One taking the first view-that Fannie and Freddie are generally doing the job that they were designed to do-might argue that "[t]he penetration of competitive markets by laws and regulations is a highly durable and robust intrusion in the U.S. economy ... [which] is arguably as tightly regulated as the more socialistic economics of Western Europe." ${ }^{192}$ Thus, there is no need to extricate the federal government from its relationship with Fannie and Freddie because the government has similar relationships with many other private companies. Proponents of this view, including trade industry powerhouses the National Association of Realtors ${ }^{193}$ and the National Association of Home Builders, ${ }^{194}$ typically recommend the limited reforms outlined in Part III.A above.

191. See Jennifer 8. Lee \& Eric Dash, Long Insulated, Fannie Mae Feels Political Heat, N.Y. TiMES, Oct. 6, 2004, at C1.

192. See Michael A. Crew \& Charles K. Rowley, Dispelling the Disinterest in Deregulation, in THe Political ECONOMY OF RENT-SEeKIng 163, 163 (Charles K. Rowley et al. eds., 1988).

193. Nat'l Ass'n of Realtors: Government Affairs, GSE Reform - REALTORS Views, http://www.realtor.org/government_affairs/gabpublic/gserealtorviews (last visited Oct. 26, 2009) (on file with the Alabama Law Review).

194. Press Release, National Association of Home Builders, Bolstering the GSEs Key to Future of Nation's Housing System (June 4, 2009), available at http://www.nahb.org/news_details.aspx?news $\mathrm{ID}=9303$. 
Affordable housing providers and advocates often take the second position: Fannie and Freddie are basically doing their job of making housing more affordable to Americans, but they are retaining too much of the value of the government guarantee for the benefit of the shareholders and management at the expense of their affordable housing goals. Given the shared agenda of Fannie and Freddie, on the one hand, and affordable housing providers and advocates, on the other, this position should not come as a surprise to a student of regulation. ${ }^{195}$ Thus, these parties favor proposals that redirect some of the excess profits of Fannie and Freddie from their shareholders and management to affordable housing programs. ${ }^{196}$

And, indeed, in a plan subsequently suspended by federal conservatorship, Congress had recently implemented an affordable housing fund in which the two firms would deposit upwards of $\$ 500$ million of their income each year. ${ }^{197}$ These monies were to be invested in affordable housing projects throughout the country. Affordable housing advocates saw this as a painless way to dramatically increase the supply of affordable housing. ${ }^{198}$ The ongoing bailout of the two companies demonstrates that the initiative was not painless, just pain deferred.

Fannie and Freddie supported this proposal in exchange for expanding their market. This expansion was implemented by increasing the conforming loan limit in high-cost parts of the country, which allowed the two companies to expand into the bottom part of the jumbo market. ${ }^{199}$ It is of note, of course, that Fannie and Freddie's support for such an extraordinarily costly initiative, as the affordable housing fund came at a low point of their public prestige, was widely seen as a political compromise that brought together a broad set of special interests whose goals are aligned

195. See Sam Peltzman et. al, The Economic Theory of Regulation after a Decade of Deregulation, in BROOKINGS PAPERS ON ECONOMIC ACTIVITY: MICROECONOMICS 1, 13 (1989) (“Compact, wellorganized groups will tend to benefit more from regulation than broad, diffuse groups. This probably creates a bias in favor of producer groups, because they are usually well organized relative to all consumers. But the dominant coalition usually also includes subsets of consumers."); SUNSTEIN, supra note 130 , at 55 (The author notes that many regulatory schemes "are designed to redistribute resources from one group to another. Some respond to a widely held or easily defended view that the benefited groups have a legitimate claim to the relevant resources.").

196. Even as persistent a GSE critic as Thomas Stanton sees some merit in this approach. He argues that such a clear-cut approach limits the ability of GSEs to manipulate their public-purposes contributions through the political process. STANTON \& MOE, supra note 111, at 107 (arguing that a potentially effective tool to assure that GSEs serve their public purposes is to "require that a GSE set aside a fixed percentage of its income to serve high-priority public purposes"). Indeed, Congress did just that with the Federal Home Loan Banks in 1989, when it required them to set aside ten percent of their income each year to reduce the costs of mortgages for underserved borrowers and communities. See id.

197. See supra note 80 and accompanying text.

198. See, e.g., Editorial, Affordable Housing, supra note 126, at A16.

199. See supra note 81 . 
with those of Fannie and Freddie ${ }^{200}$. These interests included affordable housing advocates, local governments, and the construction industry. ${ }^{201}$

The dynamics of this position are complex. Housing advocates are concerned with the sustained lack of attention that federal and state governments have paid to affordable housing policy and see any dedicated housing dollars as a long overdue priority. Implicit in this view is that the risk of a bailout of Fannie, Freddie, or both, to the typical American taxpayer is worth the benefit of the affordable housing dollars that the affordable housing fund could direct to low- and moderate-income families. The real debate, from this perspective, is how much of the golden egg of the implied subsidy from the federal government (as revealed by Fannie and Freddie's profits that exceed their industry averages) can be redirected to these affordable housing objectives without killing the Fannie and Freddie geese. $^{202}$

The third position, nationalization, has only begun to be taken seriously as the Fannie and Freddie bailouts become more and more likely. ${ }^{203}$ Indeed, then-Secretary Paulson has recently raised the idea, one which would seem to be anathema to a fiscal conservative like himself. ${ }^{204}$ Paulson proposed merging the two companies with the Federal Housing Administration, a government agency which already insures certain mortgages. He

200. See Peter J. Wallison \& Charles W. Calomiris, The Last Trillion-Dollar Commitment: The Destruction of Fannie Mae and Freddie Mac, FIN. SERVICES OUTLOOK (Am. Inst. for Pub. Policy Research, Wash., D.C.), Sept. 2008, at 8, available at http://www.law.yale.edu/documents/ pdf/cbl/Calomiris_Wallison_Last_Trillion.pdf (describing how Fannie and Freddie embraced housing goals as a strategy for managing increased political risk after their 2003 and 2004 accounting scandals).

201. See, e.g., National Housing Trust Fund, www.nlihc.org/template/page.cfm?id=40 (last visited Sept. 28, 2010) (noting that the affordable housing fund was major victory for affordable housing advocates); Mike Wallace, President Signs Federal Housing Bill, http:// www.nlc.org/ ARTICLES/ articleItems/ NCW8408/ housingbillsigned.aspx (last visited Sept. 28, 2010) (noting that affordable housing fund paid for by Fannie and Freddie was long-time policy recommendation of National League of Cities); American Institute of Architects, Housing Relief Bill Signed into Law (Aug. 8, 2008), available at http:// info.aia.org/ aiarchitect/ thisweek08/ 0808/0808n_housingbill.cfm ("AIA has supported legislation to create such a fund with its partners in the affordable housing industry.").

202. In a perverse way, it might turn out that the net impact of the guarantee of Fannie and Freddie's obligations (lower interest rates for homeowners netted from the cost of bailing out Fannie and Freddie) might actually be a progressive wealth transfer, given that roughly two-thirds of Americans are homeowners and the top twenty percent of American households pay roughly two-thirds of all federal taxes. See HARvard JOINT CENTER FOR Housing STUdIES, supra note 170, at 5 (noting homeownership rate); CONGRESSIONAL BUDGET OFFICE, HISTORICAL EFFECTIVE FEDERAL TAX RATES: 1979 TO 2004 (2006) (noting tax burden). Even if this were true, this was clearly not the intent and would be a horribly indirect way to implement public policy.

203. See Stanton \& Moe, supra note 111 at 86-87 (disfavorably comparing operations of the privately-owned Fannie Mae to those of the federal government corporation Ginnie Mae); Holman Jenkins, Jr., How To Shake off the Mortgage Mess, WALL ST. J., July 30, 2008, at A13 (arguing that Fannie and Freddie should be nationalized and then privatized); see also Wallison, Fannie and Freddie by Twilight, supra note 86 , at 4-6 (evaluating possibility of nationalizing the two companies under the Act).

204. James R. Hagerty, Paulson: Redo Fannie, Freddie, WALL ST. J., Jan. 8, 2009, at A11. 
does note, however, that such a plan would place much of the underwriting in the hands of the government, which is unlikely to do that task well (not that the private sector has done so either in recent years!). ${ }^{205}$

Since taking office, the Obama Administration has indeed looked to the GSEs as an extension of the federal government and a lever for achieving its housing policies. Fannie Mae and Freddie Mac, as conduits of federal bailout money, have effectively propped up the U.S. housing market; the two GSEs accounted for roughly seventy-five percent of all new mortgage originations in the second quarter of 2009 , with the FHA basically accounting for the remainder. ${ }^{206}$ Fannie and Freddie are also centerpieces of the Administration's foreclosure prevention efforts, refinancing and modifying mortgage loans they hold and guarantee, and further serving as the government's administrator and compliance agent in managing other industry participants in the program. ${ }^{207}$ Most recently, the Treasury employed the GSEs to support affordable housing programs, channeling money through the GSEs to purchase and securitize state and local housing agency bonds that were in demand by private investors in more flush economic times. ${ }^{208}$ This is not to suggest that nationalization of the GSEs is a fait accompli; in the months before Fannie and Freddie entered conservatorship, former Treasury secretary Lawrence Summers suggested that under an emergency scenario, the government could "operate the GSEs as a public corporation for several years . . . to extend credit where appropriate to support resolution of the housing crisis" before dividing their functions into public and private components once the crisis had passed. ${ }^{209}$

As noted above, this Article advocates for the fourth view: Fannie and Freddie pose a systemic risk to the financial system, unfairly benefit from their regulatory privilege, and do not create meaningful net benefits for the American people. ${ }^{210}$ In speaking of regulatory reform, Sunstein notes that a good first step "would be to adopt a presumption in favor of flexible, market-oriented, incentive-based, and decentralized regulatory strategies.

205. See id. The Obama Administration is signaling that it may be taking this path as well, perhaps as Fannie and Freddie become more enmeshed with the government's response to the foreclosure crisis. See Charles Duhigg, U.S. Likely to Keep the Reins On 2 Fallen Mortgage Giants, N. Y. Times, Mar. 3, 2009, at A1.

206. The Future of the Mortgage Market and the Housing Enterprises: Hearing Before the S. Comm. on Banking, Hous. and Urban Affairs, 111th Congress 5-6 (2009), available at http://banking.senate.gov/public/index.cfm?FuseAction=Files.View\&FileStore_id=2d1b87b1-d3bd4d29-91ad-fa442c3eca59 (statement of Edward J. DeMarco, Acting Director, FHFA).

207. James B. Lockhart, Director, Fed. Hous. Fin. Agency, Speech Before the Nat'l Press Club: FHFA's First Anniversary and Challenges Ahead 13 (July 30, 2009), available at http://www.fhfa.gov/webfiles/14715/FHFA1stAnnSpeechandPPT73009.pdf.

208. Nick Timiraos and Jessia Holzer, More Housing Aid is On the Way, WALl ST. J., Oct. 20, 2009 , at A5.

209. Lawrence Summers, Unfinished Business at Freddie and Fannie, WASH. POST, July 28, 2008, at $\mathrm{Al7}$.

210. See SUNSTEIN, supra note 130, at 84 ("Statutes that amount to private wealth transfers should be understood as failures per se."). 
Such strategies should be focused on ends . . . rather than on the means of achieving those ends." ${ }^{211}$ Fannie and Freddie are holdovers from an earlier philosophy of government action, one that has seen its day come and go. Indeed, if one were to create from scratch a new system of federally supported residential mortgage finance, it is quite clear that the model would not be Fannie and Freddie, which are relatively inflexible and centralized solutions to the complex and fluid problems posed by the housing finance market. And while there is an argument to be made that Fannie and Freddie are market-oriented and incentive-based, it is a stronger argument to say that they are beneficiaries of regulatory privilege with incentives that have benefited their shareholders and management disproportionately. ${ }^{212}$

Privatization is needed to remedy this state of affairs. ${ }^{213}$ Notwithstanding Fannie and Freddie's potency in Washington, this is not merely some fanciful policy proposal. Theories of regulation and rent-seeking identify erosions of government-granted monopolies over time as part of their natural life cycle. ${ }^{214}$ And, as the credit crisis continues to worsen, more and more previously unthinkable solutions are being taken quite seriously.

Four concrete plans have been recently proposed to fundamentally change Fannie and Freddie's structure, each involving different degrees of government involvement. First, convert them into cooperatives owned by lenders. Second, break the companies up into a number of smaller companies (or charter a number of similar competitors). Third, leave them intact, but regulate them like public utilities. Fourth, convert them into generic financial holding companies.

The first proposal, converting Fannie and Freddie into cooperatives, has precedent. There are two other privately owned GSEs that are cooperative lenders: the Federal Home Loan Bank System (FHLB System) and the Farm Credit System. ${ }^{215}$ Some commentators have called for the FHLB

211. Id. at 109 .

212. See Ill-Gotten Gains, supra, note 163 (noting OFHEO challenge to $\$ 115$ million in Fannie Mae executive compensation).

213. Paulson believes that this is the least attractive reform, although it is unclear from news reports why this is the case. Hagerty, Paulson: Redo Fannie, Freddie, supra note 204, at A11. Some commentators have pointed out that privatization is not a panacea for all systemic risk in the mortgage market. See, e.g., Subcomm. on Capital Markets, Insurance. and Government Sponsored Enterprises (2009), supra note 87, (prepared testimony of Dr. Susan M. Wachter, Prof. of Real Estate \& Fin., Univ. of $\mathrm{Pa}$.). Professor Wachter notes that taxpayers have been held liable for bailing out private actors as much as GSEs during the recent crisis. See id. at 2 . However, in any systemic crisis comparable to the present one, the federal government will necessarily play the role of lender of last resort. Under more common market conditions, privatization is a far superior alternative to private companies extracting monopolistic rents by exploiting a government-granted regulatory privilege.

214. See Gordon Tullock, Rents and Rent-Seeking, in THE POLITICAL ECONOMY OF THE EdUCATIONAL Process 51, 56 (Charles K. Rowley et al. eds., 1988) (“[M]onopolies provided by obtaining government action, strenuous lobbying, etc., normally also are eroded over time, partly by political forces and partly by market forces.").

215. The Federal Home Loan Bank members are lending institutions such as member institutions, federally insured savings associations, commercial banks, credit unions and insurance companies. 
System to take over Fannie and Freddie. ${ }^{216}$ This proposal has some initial attraction, as it might attenuate the short term profit-maximizing culture that characterizes publicly traded corporations like Fannie and Freddie. But history does not give comfort that such a GSE structure is superior to that of Fannie and Freddie's. Indeed, Congress had to bail out the Farm Credit System in 1987. ${ }^{217}$ And there are rumblings that the FHLB System may soon face problems similar to those of Fannie and Freddie. ${ }^{218}$

The second proposal, chartering additional housing finance competitors, has some initial attraction. Indeed, one might consider the Federal Deposit Insurance system to be a model of this: numerous recipients of regulatory privilege (access to federally guaranteed insurance) who must compete amongst themselves. If the Fannie/Freddie duopoly could be diluted with enough similar competitors, the amount of economic rent that Fannie and Freddie retain from their government guarantee subsidy should reduce significantly. In addition, one might think that a more competitive market would spread risk among more firms.

Upon further reflection, however, this proposal also reveals significant flaws. The benefit of GSE competition is less compelling now that we have experienced a bubble where so many financial institutions demonstrated herd-like behavior in their business models. And, as with the first proposal, the American taxpayer is still left with the contingent liability of the government guarantee..$^{219}$

The third proposal, regulating them like utilities, appears to be favored by Paulson ${ }^{220}$ and taken seriously by the likes of Federal Housing Finance Agency Director Lockhart. ${ }^{221}$ One worries, however, how the common regulatory problem of capture would be avoided here where the two companies to be regulated are so clearly skilled in the art of politics.

Federal Home Loan Banks, http://www.fhlbanks.com/overview_faqs.htm (last visited Sept. 28, 2010). The Farm Credit System "is a nationwide network of cooperatively organized banks and associations that are owned and controlled by their borrowers." Farm Credit Administration, http://www.fca.gov/info/index.html (last visited Sept. 28, 2010).

216. See Steven Sloan, Who Will Own Fannie, Freddie Next-FHLBs?, AM. BANK., Dec. 02, 2008, at 4. But see Hagerty, U.S. Rethinks Roles of Fannie, Freddie, supra note 87, at A5 (reporting that home builders and Realtors do not believe that bank-controlled cooperatives would provide sufficient support for housing market).

217. See Reiss, supra note 2, at 1075-76.

218. See James R. Hagerty, Home-Loan Banks Struggle To Maintain Capital, WaLl ST. J., Jan. 21,2009 , at A6.

219. The Mortgage Bankers Association has proposed a plan to transform Fannie and Freddie into two or three private companies with government charters, with the prospect of additional competitors to be chartered as the market develops. Mortgage Bankers Ass'n, MBA's Recommendations for the Future Government Role in the Core Secondary Mortgage Market 6 (Aug. 2009), available at http://www.mbaa.org/ files/ Advocacy/ 2009/ RecommendationsfortheFutureGovernmentRole.pdf.

220. See Hagerty, Paulson: Redo Fannie, Freddie, supra note 204, at A11 (reporting that Paulson said that a public utility model "could be the best way to resolve the inherent conflict" between public and private missions).

221. See Subcomm. on Capital Markets, Insurance. and Government Sponsored Enterprises (2009), supra note 87 , at 17 . 
The fourth proposal, converting them into generic financial services holding companies along the lines of institutions such as Citigroup, J.P. Morgan, and Bank of America, has the attraction of simplicity. ${ }^{222}$ It also terminates the contingent liability of the government guarantee and allows the conforming mortgage market to function like other sectors of the overall mortgage market. There is also a precedent for this approach: Sallie Mae was successfully converted from a GSE to a private company. ${ }^{223}$ This approach would also send the message that the American mortgage markets have grown up and are now to be integrated with the rest of the financial sector.

This proposal has its own limitations which must be addressed if it were to be implemented. First, because Fannie and Freddie can offer at least a short-term stabilizing role in the residential mortgage markets, the federal government would need to implement other policies to take on that role. Possible policy responses to market disruptions could include providing targeted federal mortgage guarantees, authorizing the Treasury to make mortgage-backed securities purchases, and allowing mortgage lenders to access the Federal Reserve's discount window. ${ }^{224}$ Policies like these can ensure that the residential mortgage market function during a panic.

Second, homeowners will pay slightly higher interest for conforming mortgages if the two companies are privatized. If Congress determines

222. Others have advocated this view as well. See White, supra note 172, at 17 (proposing that Fannie and Freddie be converted into standard for-profit Delaware corporations). Peter Wallison, Thomas Stanton and Bert Ely have even drafted proposed legislation to implement it. See PETER J. Wallison, et al., Privatizing Fannie MaE, Freddie MaC, and the Federal Home Loan Banks (2004). These proposals fail, however, to take into account the benefits that Fannie and Freddie offer, and thus does not make allowances for them as this Article does.

223. See Reiss, supra note 2, at 1079-80. Thomas Stanton has argued that many of Sallie Mae's GSE-derived benefits survived the termination of its GSE status: “[A]s a s GSE Sallie Mae developed the economies of scale, technological strength, low cost structure, extensive relationship with lenders and school, and rapid growth that propel the company's continuing dominance today. THOMAS Stanton, The Privatization of Sallie MaE AND its ConseQuences 41 (Report Prepared for the Amer. Enterprise Inst., 2007) Further, Stanton cautions that the student loan market's reliance on Sallie Mae raises the specter of implicit government guarantees. Id. A privatization program could address the legacy effects of GSE status by limiting the new institution's activities or encouraging entrance by competitors in the transition period before releasing the new institutions into the market. See Id. at 42-43. And just as the privatization of Sallie Mae required government satisfaction of that GSEs existing debt before releasing the company to the private sector, comparable actions would necessarily be taken for Fannie and Freddie. See Subcomm. on Capital Markets, Insurance and Government Sponsored Enterprises (2009), supra note 87 at 8 (prepared statement of Lawrence J. White, Prof. of Econ., N.Y.U.) ("The federal government will have to fill the large negative net worth 'holes' of the two companies before privatizing them; but those 'hole-filling' expenditures will be necessary regardless of what happens to the two companies, since the federal government is unlikely to stiff [the GSEs'] creditors.").

224. See David Reiss, After Fannie and Freddie, NAT'L L.J., Sept. 19, 2008, at 23 (discussing alternatives to Fannie and Freddie to stabilize mortgages markets). See also JOINT CENTER FOR Housing Studies, MeEting Multifamily Finance NeEds DuRing and AfTER the Credit Crisis 14-16 (2009), available at http://www.jchs.harvard.edu/ publications/finance/ multifamily_housing finance_needs.pdf (listing options for maintaining liquidity in face of pending reforms to GSE structure). 
that this increase is too much, particularly given the current condition of the economy, it could reduce the burden by modifying the deduction for mortgage interest or by providing a tax credit relating to mortgage interest. While such a strategy will decrease federal revenues, it will be offset by the liability that Fannie and Freddie impose on the federal government-a liability that is already on its way to costing taxpayers hundreds of billions of dollars as part of the current bailout. ${ }^{225}$

Third, if the federal government wanted to increase funding for affordable housing as contemplated in the Act, it would need to do so through direct expenditures. Again, this direct cost would be offset by terminating the contingent liability of the government guarantee..$^{226}$

Finally, Fannie and Freddie have imposed proconsumer terms on the prime conforming mortgage market. ${ }^{227}$ These must be maintained and built upon through new consumer protection regulation in order to avoid the nasty and brutish environment of the subprime mortgage market. And, indeed, it is hard to imagine that privatization would be politically feasible if such protections were not built into the privatization proposal.

Notwithstanding these limitations, the full-privatization proposal has the most going for it. It avoids the problem of the government guarantee that remains with the other three proposals. It leaves to the private sector what the private sector is supposed to do best: evaluate risk. ${ }^{228}$ And it leaves to the government what it is supposed to do best: protect against systemic risk, protect consumers, and provide affordable housing to those who could not otherwise afford it.

\section{CONCLUSION}

The main problem with GSEs is well-documented: they take on a life of their own and can survive well after they have achieved the purposes for which they are created. Alice Rivlin, in her then-capacity as the director of the Office of Management and Budget, stated that "GSEs should only be created with a clearly articulated 'exit strategy' and an express

225. See Hagerty et al., Red Ink Clouds Role of Fannie, Freddie, supra note 85, at A2 (reporting that federal government has made $\$ 400$ billion available to the two companies).

226. See supra text accompanying notes 79-80.

227. See Forrester, supra note 113, at 1087-1103 (describing pro-consumer terms in form Fannie/Freddie loan documents); Engel \& McCoy, supra note 168, at 2061, 2095 (describing due diligence best practices imposed by Fannie and Freddie).

228. Even if current events shake the faith of even the most ardent free market proponent! See Krishna Guha \& Edward Luce, Greenspan Suggests Nationalising Banks, FT.COM, Feb. 18, 2009, available at http:// www.ft.com/ cms/s/0 /e310cbf6 -fd4e-11dd-a103000077b07658.html?nclick_check=1 (quoting Alan Greenspan as saying, "It may be necessary to temporarily nationalise some banks in order to facilitate a swift and orderly restructuring."). 
sunset date in their charter." ${ }^{229}$ Unfortunately, this is almost never the case.

The typical result of poor GSE design is that the GSE ends up driving much of the legislative and regulatory agenda regarding its own fate. Stanton and Moe argue that this can lead to "increasing dominance over the governmental process" by GSEs; the inability "of the government to supervise GSE safety and soundness and the government's resulting financial exposure;" as well as government inability "to induce GSEs to serve public purposes that conflict with the interests of shareholders." 230

Fannie and Freddie reflect what is worst in GSE design. After fulfilling their purpose of creating a national mortgage market, they have taken on monstrously large lives of their own. In the midst of their bailout, Congress should take the opportunity to convert them to fully private status. Congress should also enact appropriate financial regulation, consumer protection legislation, and affordable housing programs. And Congress should remember the lessons of Fannie and Freddie when it considers using the GSE as a tool of government in the future. It should reflect on the appropriate design for such a hybrid tool-a design informed by a theoretical understanding of the GSE based on regulatory theory and sound federal budget policies.

229. OFFICE OF MGMT. AND BUdGET, MEMORANDUM ON GOVERNMENT CORPORATIONS, supra note 97, at 14. Designers of future hybrids should not be surprised "if hybrid organizations acquire unusual political influence due to their unique combination of public- and private-sector advantages." KopPell, supra note 126 , at 121. See also BARRY M. MITNICK, THE POLITICAL ECONOMY OF Regulation: Creating, Designing ANd Removing Regulatory Forms 34, 206 (1980) (describing the "life cycle" model of regulated industries, frequently ending in regulatory capture).

230. Stanton \& Moe, supra note 111 , at 105. 
